\title{
Impact of agricultural farms on the environment of the Puck Commune: Integrated agriculture calculator - CalcGosPuck
}

\author{
Lidia Dzierzbicka-Glowacka ${ }^{\text {Corresp.. }}{ }^{1}$ ， Stefan Pietrzak ${ }^{2}$ ， Dawid Dybowski ${ }^{1}$, Michał Białoskórski ${ }^{3}$, Tadeusz \\ Marcinkowski $^{2}$, Ludmiła Rossa ${ }^{2}$, Marek Urbaniak ${ }^{2}$, Zuzanna Majewska ${ }^{2}$, Dominika Juszkowska ${ }^{2}$, Piotr \\ Nawalany $^{2}$, Grażyna Pazikowska-Sapota ${ }^{4}$, Bożena Kamińska ${ }^{5}$, Bartłomiej Selke ${ }^{5}$, Paweł Korthals ${ }^{5}$, Tadeusz \\ Puszkarczuk ${ }^{5}$ \\ ${ }^{1}$ Physical Oceanography Department, Ecohydrodynamics Laboratory, Institute of Oceanology of the Polish Academy of Sciences, Sopot, Poland \\ 2 Department of Water Quality, Institute of Technology and Life Sciences in Falenty, Raszyn, Poland \\ 3 Academic Computer Centre in Gdańsk, Gdańsk, Poland \\ 4 Department of Environment Protection, Maritime Institute in Gdańsk, Gdańsk, Poland \\ 5 Municipality of Puck, Puck, Poland \\ Corresponding Author: Lidia Dzierzbicka-Glowacka \\ Email address: dzierzb@iopan.gda.pl
}

Background. Leaching of nutrients from agricultural areas is the main cause of water pollution and eutrophication of the Baltic Sea. A variety of remedial actions to reduce nitrogen and phosphorus losses from agricultural holdings and cultivated fields have been taken in the past. However, knowledge about the risk of nutrient leaching has not yet reached many farmers operating in the water catchment area of the Baltic Sea.

Methods. The nutrient balance method known as "At the farm gate" involves calculating separate balances for nitrogen $(\mathrm{N})$, phosphorus $(\mathrm{P})$ and potassium $(\mathrm{K})$. After estimating all the components of the nutrient balance, the total balance for NPK is calculated and the data obtained is expressed as the ratio of total change (surplus) to the area of arable land on a farm. In addition, the nutrient usage efficiency on a farm is also calculated. An opinion poll was conducted in 2017 on 3.6 percent $(n=31)$ of the farms located in commune of Puck. The total area of the farms including arable and grass land ranged from 5130 ha with an average of $45.82 \mathrm{ha}$. The arable land was on average 30.79 ha ranging from $4.45-130$ ha while the grassland averaged 12.77 ha and ranged from 0-53 ha.

Results. The average consumption of mineral fertilizer in the sample population of farms was $114.9 \mathrm{~kg}$ $\mathrm{N}, 9.3 \mathrm{~kg} \mathrm{P}$, and $22.9 \mathrm{~kg} \mathrm{~K} \cdot$ ha-1 of agricultural land $(\mathrm{AL})$, respectively. $\mathrm{N}$ balance in the sample farms being ranged from -23.3 to $254.5 \mathrm{~kg} \mathrm{~N} \cdot \mathrm{ha}^{-1} \mathrm{AL}$ while nutrient use efficiency ranged from 0.40 to 231.3 percent. In comparison, $\mathrm{P}$ surplus in the sample farms was $5.0 \mathrm{~kg} \mathrm{P} \cdot \mathrm{ha}^{-1} \mathrm{AL}$ with the $\mathrm{P}$ use efficiency of $0.4-266.5$ percent.

Discussion. Mean $\mathrm{N}$ fertilizer consumption in the tested farms was higher than the average usage across Poland and in the Pomeranian Voivodeship. However, mean consumption of potassium fertilizers was lower than mentioned averages. Mean P fertilizer consumption was higher than in the Pomeranian Voivodeship, but lower compared to the entire country. Generally, on the basis of designated research indicators of farm pressures on water quality, concentrations of total nitrogen and total phosphorus were obtained. CalcGosPuck (an integrated agriculture calculator) will help to raise farmers' awareness about NPK flow on farm scale and to improve nutrient management. 


\section{Impact of agricultural farms on the environment of the Puck}

\section{Commune: Integrated agriculture calculator - CalcGosPuck}

3 Lidia Dzierzbicka-Glowacka ${ }^{1}$, Stefan Pietrzak ${ }^{2}$, Dawid Dybowski ${ }^{1}$, Michał Białoskórski ${ }^{3}$,

4 Tadeusz Marcinkowski², Ludmiła Rossa², Marek Urbaniak ${ }^{2}$, Zuzanna Majewska ${ }^{2}$,

5 Dominika Juszkowska ${ }^{2}$, Piotr Nawalany ${ }^{2}$, Grażyna Pazikowska-Sapota ${ }^{4}$, Bożena Kamińska ${ }^{5}$,

6 Bartłomiej Selke ${ }^{5}$, Paweł Korthals ${ }^{5}$, Tadeusz Puszkarczuk ${ }^{5}$

7

8 1Physical Oceanography Department, Ecohydrodynamics Laboratory, Institute of Oceanology of

9 the Polish Academy of Sciences, Sopot, Poland

${ }^{2}$ Department of Water Quality, Institute of Technology and Life Sciences in Falenty, Raszyn,

11 Poland

$12{ }^{3}$ Academic Computer Centre in Gdańsk, Gdańsk, Poland;

$13{ }^{4}$ Department of Environment Protection, Maritime Institute in Gdańsk, Gdańsk, Poland;

$14{ }^{5}$ Municipality of Puck, Puck, Poland;

Corresponding Author:

Lidia Dzierzbicka-Glowacka

Powstańców Warszawy 55, 81-712 Sopot, Poland, P.O. Box 148

E-mail address: dzierzb@iopan.gda.pl 


\section{Abstract}

Background. Leaching of nutrients from agricultural areas is the main cause of water pollution and eutrophication of the Baltic Sea. A variety of remedial actions to reduce nitrogen and phosphorus losses from agricultural holdings and cultivated fields have been taken in the past. However, knowledge about the risk of nutrient leaching has not yet reached many farmers operating in the water catchment area of the Baltic Sea.

Methods. The nutrient balance method known as "At the farm gate" involves calculating separate balances for nitrogen $(\mathrm{N})$, phosphorus $(\mathrm{P})$ and potassium $(\mathrm{K})$. After estimating all the components of the nutrient balance, the total balance for NPK is calculated and the data obtained is expressed as the ratio of total change (surplus) to the area of arable land on a farm. In addition, the nutrient usage efficiency on a farm is also calculated. An opinion poll was conducted in 2017 on 3.6 percent $(n=31)$ of the farms located in commune of Puck. The total area of the farms including arable and grass land ranged from 5-130 ha with an average of 45.82 ha. The arable land was on average 30.79 ha ranging from $4.45-130$ ha while the grassland averaged 12.77 ha and ranged from 0-53 ha.

Results. The average consumption of mineral fertilizer in the sample population of farms was $114.9 \mathrm{~kg} \mathrm{~N}, 9.3 \mathrm{~kg} \mathrm{P}$, and $22.9 \mathrm{~kg} \mathrm{~K} \cdot \mathrm{ha}^{-1}$ of agricultural land (AL), respectively.

$\mathrm{N}$ balance in the sample farms being ranged from -23.3 to $254.5 \mathrm{~kg} \mathrm{~N} \cdot \mathrm{ha}^{-1} \mathrm{AL}$ while nutrient use efficiency ranged from 0.40 to 231.3 percent. In comparison, $\mathrm{P}$ surplus in the sample farms was $5.0 \mathrm{~kg} P \cdot \mathrm{ha}^{-1} \mathrm{AL}$ with the P use efficiency of 0.4-266.5 percent.

Discussion. Mean $\mathrm{N}$ fertilizer consumption in the tested farms was higher than the average usage across Poland and in the Pomeranian Voivodeship. However, mean consumption of potassium fertilizers was lower than mentioned averages. Mean $\mathrm{P}$ fertilizer consumption was higher than in the Pomeranian Voivodeship, but lower compared to the entire country. Generally, on the basis of designated research indicators of farm pressures on water quality, 57 concentrations of total nitrogen and total phosphorus were obtained. CalcGosPuck (an integrated agriculture calculator) will help to raise farmers' awareness about NPK flow on farm scale and to improve nutrient management. 
60

61

\section{Main article text}

\section{Introduction}

Leaching of nutrients from agricultural areas is the main cause of water pollution and eutrophication of the Baltic Sea. A variety of remedial measures to reduce Nitrogen $(\mathrm{N})$ and Phosphorus (P) losses from agricultural holdings have been taken in the past. However, knowledge about the risk of nutrient leaching has not yet reached many farmers operating in the watershed areas of the Baltic Sea. Nevertheless, the growing international consciousness on the need for water quality improvement has influenced the desire to expand knowledge and social awareness of environmental implications of water quality worldwide. There are relatively cheap and simple prevention measures (e.g., crop rotation, soil fertility analysis, separation of pastures from water courses and reservoirs or systematic on-farm Advisory Services), but not all of them have been implemented or entered into the list of 25 priority measures set out within the framework of the Baltic Compass project (Salomon, Sundberg, 2012). One of the reasons for this is that these measures should be worked out in practice by farmers based on their knowledge, and then adapted to the given farming conditions (Ulén et al., 2013).

The farm is the basic organizational unit in agriculture and it produces food and raw materials for industry. Production involves a large quantity of nutrients, only a fraction of which is converted into animal and vegetable products. The surplus of the unused nutrients in production accumulates in the soil, or are lost to surface waters, drain water, groundwater, or to the atmosphere. The loss of nutrients is an economic cost in terms of reduced production obtained with higher cost of inputs and poses a threat to the environment. $\mathrm{N}$ and $\mathrm{P}$ compounds are of special concern in environmental quality management because they are lost through several pathways such as surface runoff, subsurface flow and leaching within soils, water and wind erosion, emissions of gaseous forms of $\mathrm{N}$ and their deposition by atmospheric precipitation (Pietrzak, 2013).

Arguably, nutrient losses are inevitable; however, given their environmental and the economic impacts on production and environmental quality, they should be kept below acceptable minimum thresholds. Therefore, it is essential to create farm production thresholds to ensure effective nutrient management. The "At the farm gate" method is one way to conduct a nutrient balance for a farm. This method is a good educational and decision support tool in the area of agricultural production activities, for such entities as farmers, agricultural advisors, agricultural 
91 school and university teachers as well as employees of state and local government institutions

92 who are responsible for agri-environmental policy implementation. It is particularly important

93 for farmers and agricultural consultants and advisors cooperating with them. In this partner

94 system, the "At the farm gate" method is used as a measure that could potentially improve the

95 efficiency of fertilizer components management in an agricultural holding, which is a beneficial

96 factor for both economic and environmental reasons. Therefore, farmers and agricultural

97 advisors must be trained to acquire the knowledge and skills to estimate nutrient balances

98 (Pietrzak, 2013). However, there are best practices for increasing nutrient use efficiency in order

99 to reduce expenditure on fertilizers use and feed in commercial agriculture. These entail use of

100 computer programs to estimate nutrient balances in the farm especially for NP. In the United

101 Kingdom, for example, the software for calculating "At the farm gate" nutrient balance is

102 available free of charge for farmers and agricultural advisors as a module of the PLANET

103 (Planning Land Applications of Nutrients for Efficiency and the Environment) system (Farmgate

104 Nutrient Balance Help file). In Sweden, a computerized NPK balancing system called “Greppa

105 Näringen i.e. Focus on nutrients" was implemented on a large scale (Nilsson, 2016) and used by

106 farmers in cooperation with agricultural advisors on a voluntary basis and makes significant

107 impact (Jakobsson, 2012). Furthermore, in the United States, the application for balancing

108 fertilizer components on the farm was disseminated nationwide as part of the "Livestock and

109 Poultry Environmental Stewardship - LPES” program (Koelsch; Koelsch, Franzen, 2002).

110 The research presented in this paper was conducted as part of the project on modelling of the

111 impact of the agricultural holdings and land-use structure on quality of water in the Bay of Puck -

112 Integrated information and forecasting Service "WaterPUCK" (Dzierzbicka-Glowacka et al., 113 2018).

114 The purpose of the project was to determine the current and future environmental status of

115 surface water and groundwater quality in the Puck Commune and its impact on the Bay of Puck

116 environment (Fig. 1). The most significant input of nutrients and pesticides in the environment

117 comes from agricultural source and surface structure usage e.g. sewers or drainage ditches.

118 Therefore, objective of the project was to estimate the impact of nutrient loading by compiling

119 the recent knowledge, factoring in the essential in situ measurements, and using advanced

120 modelling.

121 


\section{Material and methods}

\section{Integrated agriculture calculator - CalcGosPuck}

124 The web tools obtained within the project (service WaterPUCK with CalcGosPuck) were

125 modified account for many innovative measures, processes and models to provide a basis for the

126 "green economy" development that could be implemented in other Baltic Sea catchment areas.

127 This is in line with the objectives of European legislation, including: i) the Nitrates Directive

128 (91/676/EEC), ii) the Water Framework Directive (2000/60/EC), iii) the Marine Strategy

129 Framework Directive (2008/56/EC) and iv) the Habitats Directive (92/43/EEC) as well as with

130 the HELCOM Baltic Sea Action Plan and the strategic program of environmental protection for

131 the Puck Commune.

132 The WaterPUCK service (Fig. 2) includes the following: a surface water model based on SWAT, 133 a groundwater flow model "GroundPuck" based on Modflow, a 3D environmental model of the 134 Bay of Puck "EcoPuckBay" based on the POP code and an integrated agriculture calculator 135 called "CalcGosPuck". The CalcGosPuck, presented in this paper, was developed as the first 136 module of the WaterPuck service. Data obtained from farms and defined in this model were used 137 to determine fertilizer components loads released from agricultural production to the 138 environment, including surface and groundwater.

139

\section{The general concept of nutrient balance on farms}

141 The "At the farm gate" nutrient balance method usually involves calculating separate balances 142 for NPK nutrient elements. The principle is the same for all three nutrients, with the exception 143 that the $\mathrm{N}$ balance sheets include more factors because of larger number of $\mathrm{N}$ nutrient sources 144 into the farms (e.g. legumes crops, deposition from the atmosphere). The procedure for 145 establishing balance of nutrients using the "At the farm gate" method has been described in 146 detail by Pietrzak (2013). Preparation of the nutrient balance using "At the farm gate" method 147 involves determination of input and output streams on the farm (Fig. 3).

148 The mass of nutrients imported onto a farm is calculated as the amount of input in: i) mineral 149 fertilizers (own study based on data producers of mineral fertilizers); ii) purchased concentrated 150 fodders (Mercik, 2002); iii) purchased bred animals (Fagerberg et al., 1993; Wrzaszcz, 2009;

151 Rutkowska, 2010; Szewczuk, 2010); iv) natural fertilizers (farm-produced or externally 152 purchased manure) (Maćkowiak, 1997; Grabowski, 2009); v) other purchased products 
153 (Fagerberg et al., 1993; Wrzaszcz, 2009; Rutkowska, 2010; Szewczuk, 2010); vi) atmospheric

154 deposition (adopted for the Pomeranian Voivodeship) (IMGW); vii) symbiotically fixed nitrogen

155 (Schmidtke, 2008; Høgh-Jensen et al., 2004); viii) nitrogen introduced by free-living soil

156 microorganisms (Mazur, 1991); while the masses of nutrients exported from the farm are

157 calculated as the amount of output in sold animal and plant products (Fagerberg et al., 1993;

158 Wrzaszcz, 2009; Rutkowska, 2010; Szewczuk, 2010).

159

160 Estimating nutrient balance and usage efficiency

161 After estimating all the components of the nutrient balance, the total balance (surplus or deficit)

162 for N, P and K was calculated as a difference between inputs and outputs. The data obtained was

163 then expressed as a ratio of total change to area of agricultural land on the farm and the nutrient

164 usage efficiency on the farm was calculated. The use efficiency of NPK is the ratio of the amount

165 leaving the farm (outputs in plant and animal products, not including leaching, volatilization) to

166 the amount entering the farm (inputs) expressed as a percentage. The nutrient usage efficiency

167 was then used to define the percentage of nutrients brought into the farm, which are used directly

168 for production.

169 Analysis of the correlation between $\mathrm{N}$ and $\mathrm{P}$ surplus and selected elements of the balance of

170 these components was carried out using the STATISTICA 7 Soft. The nonparametric method of

171 calculating the Spearman rank correlation coefficient was used, because the data was not

172 normally distributed (Spearman, 1904).

173

174 Farms in the Puck Commune

175 Agricultural lands and livestock production

176 An opinion poll was conducted on 31 farms within the Commune of Puck, which is

177 approximately 3.6 percent of all farms in this Commune. The average area of the farms is 45.82

178 ha with a range of 5 to 130 ha including arable land. The average area of arable land is 30.79 ha

179 with a range of 4.45 to 130 ha while the mean area of grassland is 12.77 ha ranging from zero to 18053 ha (Fig. S1).

181 Within the test area of the agricultural land, the majority of soils $(90.3 \%, \mathrm{n}=28)$ are medium -

182 Category III (21-35\% content of particles with diameter less than $0.02 \mathrm{~mm}$ ) (Jadczyszyn et al., 183 2016). The soils in the remaining farms $(9.7 \% \mathrm{n}=3)$ include light texture soils (11-20\% content) 
184 (Fig. S2). The types and areas of the field-scale crops and grasslands in farms participating in the 185 WaterPUCK project are given in Fig. 4, and animal population, type, and the barn maintenance 186 systems are given in Table 1.

187 The profile of production systems in the study farms is presented in Table 2.

188 In the majority of farms $(96.8 \%, n=30)$ the management system of livestock manure was the 189 slurry and solid manure system, in which animals are maintained in livestock buildings on a 190 shallow litter. An exception was the farm marked Code 29, where some of the young animals 191 (calves and heifers) were kept in deep leaf litter, and one small farm (Code 31) where all the 192 animals (calves and piglets) were kept in a deep barn, in a total of 1.3 of livestock unit (LU). The 193 livestock density was variable ranging from

a) $0.1-1.0 \mathrm{LU} \cdot \mathrm{ha}^{-1}$ on fourteen farms;

b) $1.1-2.0 \mathrm{LU} \cdot \mathrm{ha}^{-1}$ on nine farms; and

196

c) $2.1-3.0 \mathrm{LU} \cdot \mathrm{ha}^{-1}$ on two farms.

In the high density farms (c) the mass of nitrogen produced in natural fertilizers per hectare was 198 relatively high, with values ranging from 138 to $145 \mathrm{~kg} \mathrm{~N} \cdot \mathrm{ha}^{-1}$. However, it did not exceed the limit of land application of $170 \mathrm{~kg} \mathrm{~N} \cdot \mathrm{ha}^{-1}$ per year stated in the Nitrates Directive. In a small portion of the farms (Codes: 9, 11, 20 and 23) involved in the production of milk and 201 beef livestock, animals have periodically been at pasture. The farm marked Code 27, which breeds and raises horses, has also been using pastures.

\section{Crop rotation and after-crops}

205

Out of the Puck Commune farms surveyed, the vast majority of them $(96.8 \%, n=30)$ practice crop rotation. The most common $(76.6 \%, \mathrm{n}=23)$ kind of crop rotation was cereal rotation (the share of cereal plants above $60 \%$ ). The most distinctive types of cereal rotation were silage maize-winter wheat-spring grain mixtures, winter wheat-spring wheat-winter wheat-oat and spring barley-oat-spring grain mixtures-potatoes.

210 The most relevant rotation was field-corn cereal (above 60\%), on 23 farms $(76.7 \%)$. Only 19.4 percent $(n=6)$ out of all farms use after-crops (a later crop of the same year from the same soil). In farms with additional vegetative cover two types of after-crops - catch crops and mixed cropping (companion crops), have been equally preferred. These after-crops were in the 
214 majority of cases $(83.3 \%, n=5)$ incorporated in green manure. The cultivated area with after-

215 crops ranged from 14.4 to 35.7 percent of farms' total arable lands.

216

\section{Storage of natural fertilizers and silage}

218 In all sample farms all structures used for the storage of manure regardless of size meet the requirements of Polish legislation "Action program aimed at reducing the outflows of nitrates

220

221

222

223

224

225

226

227

228

229

230

231

232

233

234

235

236

237

238

239

240

241

242

243

from agricultural sources" (J. of Laws, 2018 item 1339) for minimum distance of 20 meters from wells, edges of waterways and reservoirs. Moreover, a large proportion $(82.6 \%, n=19)$ of the dung panels and tanks for manure are less than 14 years old. Thus, there is a high probability of effectively stopping leachate of manure and slurry leakage (Fig. S3). In three farms manure was stored directly on the ground, but the piles are located on flat terrain where the soil is neither sandy nor waterlogged at a distance of more than $20 \mathrm{~m}$ from the edges of waterways and reservoirs. However, one of the farms was obligated to have a slurry storage tank, due to the litter-free system of keeping livestock. On this farm the current tank was made in 2013 and is located at a distance of more than $20 \mathrm{~m}$ from the protected zones of water sources and water intakes and the of the edges of reservoirs and waterways. In almost 50 percent of the farms $(n=16)$, the most common practice to store compacted silage is special plastic bales that limit the risk of silage juice although, about 30 percent $(n=9)$ silage is stored in field piles directly on the grounds less frequently.

\section{Permitted dates to use natural fertilizers}

In accordance with the Polish law - Act of July 10, 2007 on fertilizers and fertilizing (J. of Laws, 2007 No. 147, item 1033), natural and organic fertilizers, in either liquid or solid form (manure, liquid slurry, slurry), were allowed to be applied on field between March 1st and November 30th. Permitted dates of solid manure use on arable lands and liquid natural fertilizers use (manure, slurry) on permanent meadows with marked dates of fertilizer uses by farmers in the Puck Commune are given in Figs S4 and S5, respectively.

\section{Results}

\section{Integrated agriculture calculator - CalcGosPuck}


244 In accordance with the "At the farm gate" concept method, the agriculture calculator

245 “CalcGosPuck” was developed. The CalcGosPuck calculator works as an independent

246 application designed to calculate the nutrient inputs and outputs, and then the surplus/deficit and

247 the nutrient use efficiency on a farm. The user gives the farm size and selects the required

248 province, input and output products for balance and gives their amount. CalcGosPuck works

249 properly (see the website www.waterpuck.pl in Service - Fig. 5).

250 One should enter specified data (Fig. 6) into the CalcGosPuck calculator in order to determine

251 inputs, outputs, NP surplus (or deficit) and the use efficiency of nutrients on the farm: i) the area

252 of agricultural land of the farm (in hectares) (Fig. 6a); ii) the province in which the farm operates

253 (Fig. 6b); iii) select indicators of what is imported onto the farm (mineral fertilizers, concentrated

254 fodder (mixed cattle feed, mixed pig feed, mixed poultry feed), purchased animal products,

255 natural fertilizers, other purchased plant products, by atmospheric precipitation, by legumes, and

256 fixed by soil microorganisms) (Figs. 6c); iv) select indicators of what is exported from the farm

257 (in animal and plant products sold) (Fig. 6d); v) give the amount of each selected indicator (Fig.

258 6e). After each parameter is selected, the basic data are automatically set down input, output,

259 surplus (or deficit = value with a minus sign) and the data related to the efficiency of the farm are

260 displayed in the top bar (Fig. 6f).

261

262 Case Study Application of the Calculator (on the example of a farm marked Code 9)

263 Step 1: Enter the area of agricultural land [in ha]: 70;

264 Step 2: Select the Voivodeship: Pomerania;

265 Step 3: Select inputs and their amounts:

266

267

268

269

270

271

- $\quad$ in mineral fertilizers: urea $=100 \mathrm{dt}$, ammonium nitrate $=50 \mathrm{dt}$,

- in energy and protein fodders: rape cake for animals $=240 \mathrm{dt}$, dried pulp $=150 \mathrm{dt}$, post-extraction soya meal $=400 \mathrm{dt}$;

- in other plant and animal products: maize (grain) $=120 \mathrm{dt}$, heifers $=15 \mathrm{dt}$;

Step 4: Select outputs and their amount:

272 Step 5: Results of the calculations (Fig. 6f):

273 Budget:

$274 \quad$ Inputs: $\quad \mathrm{N}: 10996.00 \mathrm{~kg} ; \quad \mathrm{P}: 609.00 \mathrm{~kg} ; \quad \mathrm{K}: 645.95 \mathrm{~kg}$; 


$\begin{array}{lllll}275 & \text { Outputs: } & \text { N: } 1977.50 \mathrm{~kg} ; & \text { P: } 375.90 \mathrm{~kg} ; & \mathrm{K}: 530.95 \mathrm{~kg} ; \\ 276 & \text { Surplus: } & \text { N: } 9018.50 \mathrm{~kg} ; & \text { P: } 233.10 \mathrm{~kg} ; & \mathrm{K}: 115.00 \mathrm{~kg} ; \\ 277 & \text { Efficiency: } & \text { N: } 17.98 \% ; & \text { P: } 61.72 \% ; & \mathrm{K}: 82.20 \% .\end{array}$

279 Consumption of natural fertilizers

280 The average consumption of mineral NPK ha ${ }^{-1}$ in the study area ranged within the respective

281 levels of: $114.9 \mathrm{~kg} \mathrm{~N}, 9.3 \mathrm{~kg} \mathrm{P}$, and $22.9 \mathrm{~kg} \mathrm{~K} \cdot \mathrm{ha}^{-1} \mathrm{AL}$. On the individual farms, consumption of 282 the components listed was highly variable with a range $0-232.6 \mathrm{~kg} \mathrm{~N} \cdot \mathrm{ha}^{-1}$ (Fig. 7); $0-31.2 \mathrm{~kg}$ 283 P.ha-1 (Fig. 8) and $0-159.6 \mathrm{~kg} \mathrm{~K} \cdot \mathrm{ha}^{-1}$ (Fig 9).

284

285

286

287

288

289

290

291

292

293

294

295

296

297

298

299

300

301

302

303

304

305

\section{Environmental aspects of fertilizer usage}

With regard to the conditions of fertilizers application, it was determined that:

- On 29 out of the 31 tested farms (93.5\%), the annual dosages of nitrogen fertilizers (mineral, natural, organic) were divided into parts during the growing season, usually into three in case of arable lands and two fertilizations of permanent meadows.

- On 19 farms (61.3\%) have arable land on parcels with steep slopes (more than 10\%). On 16 out of them (84.2\%) the general rules of fertilizer usage on steep slopes were taken. In only two agricultural holdings $(10.5 \%)$ the rules have not been followed. In cases of parcels with a slope of more than $10 \%$, cultivation treatments have been carried out in a direction transverse to the slope leaving the ridge up the slope.

- On 2 farms (6.5\%) fertilizers were applied on field in situations when the soils was flooded, covered by snow or frozen to a depth of 30 centimeters, and during rainfall. Municipal sewage sludge has not been used in areas of special flood hazard, temporarily flooded and swampy areas, or on high permeability areas on any of the farms.

- On the majority of the tested farms $(87.1 \%, \mathrm{n}=27)$, there were agricultural lands located at a distance of less than 50 meters from the edges of waterways and lakes. On the other hand, on most of them $(63 \%, \mathrm{n}=17)$ in the areas close to waterways or reservoirs, fertilization has not been used. In 6 cases (22.2\%) fertilization has been used at a distance less than 20 meters from the edges of waterways and lakes.

- Records of agricultural treatments containing information about dates and doses of fertilization were being kept on 23 agricultural holding (74.2\%). On the remaining 7 
306

307

308

309

310

311

312

313

314

315

316

317

318

319

320

321

322

323

324

325

326

327

328

329

330

331

332

333

334

335

336

farms (22.6\%) agro-technical practices were not documented and on one - there were no data.

- Only one of the analyzed farms (3.2\%) kept records of natural fertilizers disposal (agreement for sale of any surpluses).

- Nitrogen balance estimation and fertilization plans were being developed on 20 (64.5\%) of all the farms. In remaining ones, there were either no balance sheets and fertilization plans or there was no information about that.

\section{The Surplus and Use Efficiency of Nitrogen, Phosphorus and Potassium}

Nitrogen balances on the analyzed farms ranged from -23.3 to $254.5 \mathrm{~kg} \mathrm{~N} \cdot \mathrm{ha}^{-1} \mathrm{AL}$ while $\mathrm{N}$ use efficiency ranged from 0.40 to 231.3 percent (Fig. 10). The lowest efficiency, 0.4 percent, was observed in the horse-breeding farm (Code 27) while the highest level, 231.3 percent, was recorded in the sole plant production farm (Code 17). The average nitrogen surplus in all 31 farms was $120.6 \mathrm{~kg} \mathrm{~N} \cdot \mathrm{ha}^{-1} \mathrm{AL}$ while efficiency of this component use was 31.8 percent.

In the case of phosphorus, the average P surplus/deficit value for all farms was $5.0 \mathrm{~kg} \mathrm{P} \cdot \mathrm{ha}^{-1} \mathrm{AL}$ (Fig. 11) with a farm range of -17.11 to $28.7 \mathrm{~kg} \mathrm{P} \cdot \mathrm{ha}^{-1} \mathrm{AL}$ (Fig. 11). The average P use efficiency was 66.2 percent while on farms ranged from 0.4 to 266.5 percent.

Potassium balances and use efficiency on study farms ranged from -54.1 to $159.8 \mathrm{~kg} \mathrm{~K} \cdot \mathrm{ha}^{-1} \mathrm{AL}$ and from 1.5 to $432.3 \%$, respectively (Fig. 12). The average $\mathrm{K}$ surplus value was $10.8 \mathrm{~kg} \mathrm{~K} \cdot \mathrm{ha}^{-1}$ AL while average $\mathrm{K}$ use efficiency was $62.2 \%$.

With regard to all agricultural holdings, in general structure of $\mathrm{N}$ inputs the largest amounts came from mineral fertilizers (65\%) and purchased concentrated fodder $(17.7 \%)$. The next order was as follows: legumes (6.3\%), atmospheric precipitation (5.1\%), soil microorganisms (4.2\%) and others $(0.6 \%)$. In structure of $\mathrm{N}$ outputs, the largest amount was nitrogen sold in plant products $(62.3 \%)$ while the remaining $\mathrm{N}$ part $(37.7 \%)$ was sold in animal products.

In $\mathrm{P}$ balance, the order of the largest proportions of $\mathrm{P}$ input was mineral fertilizers $(63 \%)$, purchased concentrated fodder (32.7\%), atmospheric precipitation $(2.5 \%)$, others $(1.6 \%)$, while P was output in sold plant (57.4\%) and animal products $(32.7 \%)$.

As with $\mathrm{N}$ and $\mathrm{P}$, in $\mathrm{K}$ balance the order of inputs was mineral fertilizers $(79.4 \%)$, purchased concentrated fodder (10.6\%), atmospheric precipitation $(9.1 \%)$ and others $(0.9 \%)$. In structure of K outputs sold, plant products $(77.4 \%)$ predominated over animal products $(22.6 \%)$. 
338 Discussion

339 Impact of agricultural farms on the environment of the Puck Commune caused by dispersion of

340 fertilizer components, was determined by a set of natural and anthropogenic factors conditioning

341 the activities of these farms. Undoubtedly, the most important factors were those that concerned

342 the use of mineral fertilizers. Nitrogen fertilizers consumption in the tested farms was higher

343 than average usage across Poland and in the Pomeranian Voivodeship, compared to the lesser

344 consumption of potassium fertilizers (Table 3). Phosphorus fertilizers consumption was higher

345 than in the Pomeranian Voivodeship, but lower compared to the entire country. Most of the

346 farms of the Puck Commune used N fertilizers in doses of 50-100 (35.5\%, n=11) and 100-150

$347 \mathrm{~kg} \mathrm{~N} \cdot \mathrm{ha}^{-1} \mathrm{AL}$ (the same) while P fertilizers in doses of $10-15 \mathrm{~kg} \mathrm{P} \cdot \mathrm{ha}^{-1} \mathrm{AL}(32.3 \%, \mathrm{n}=10)$ and 5-

$34810 \mathrm{~kg} \mathrm{P} \cdot \mathrm{ha}^{-1} \mathrm{AL}(25.8 \%, \mathrm{n}=8)$. In case of $\mathrm{K}$ fertilizers, the largest two groups of farms $(35.5 \%$,

$349 \mathrm{n}=11$ ) used them in doses of $0-20$ and 20-40 $\mathrm{kg} \mathrm{K} \cdot \mathrm{ha}^{-1} \mathrm{AL} \cdot \mathrm{N}: \mathrm{P}_{2} \mathrm{O}_{5}: \mathrm{K}_{2} \mathrm{O}$ ratio in average fertilizer

350 dose for all farms was 1.0:0.19:0.24 (what means that for every $1 \mathrm{~kg}$ of $\mathrm{N}$ only $0.19 \mathrm{~kg}$ of $\mathrm{P}_{2} \mathrm{O}_{5}$

351 and $0.24 \mathrm{~kg}$ of $\mathrm{K}_{2} \mathrm{O}$ were applied). These proportions may raise some doubts in the light of the

352 general recommendations of crop fertilization. According to them, 1.00:0.50:0.98 proportions

353 are recommended for fertilization that is sustainable for field crops in Polish soil conditions and

354 1.00:0.46:0.68 for permanent grassland (Kucharska et al., 1996). It should be also emphasized

355 that in conditions of wrong N:P:K ratios in fertilizers usage there may occur some disturbances

356 in process of $\mathrm{N}$ acquirement by plants and increased losses of this component, causing

357 environmental hazards.

358 Considering the environmental aspects of fertilizer usage, it can be concluded that the majority

359 of farms in the Puck Commune used the correct approach in mineral fertilizers management

360 (e.g. dividing doses, not using fertilizers in high-risk conditions, observing rules for fertilizer use

361 on slopes, no fertilizers in proximity to surface water, keeping agro-technical practices records).

362 However, in most of farms there were natural conditions that could create increased fertilizers

363 losses during their application, especially in which arable lands were located in steep-slope areas

364 (more than $60 \%$ of all farms). On such plots, surface runoff could be formed, delivering

365 nutrients from land to watercourses and water reservoirs. Therefore, this could lead to their

366 eutrophication (Andraska, Bundy, 2003; Miller et al. 2011). Therefore, the higher fertilizers 
367 doses were used, the greater could be the loss of nutrients by surface runoff (Thayer, 2011;

368 Smith, Jackson, Pepper, 2001).

$369 \mathrm{NP}$ and K in mineral fertilizers constituted the largest shares in total components input brought

370 onto the analyzed farms from outside (on average, 65.0, 63.0 and 79.4 percent, respectively).

371 Moreover, the relationship between N, P and K content in mineral fertilizers and their surplus

372 generated by farms has a strong positive correlation (Table 4-6). The average $\mathrm{N}$ and $\mathrm{K}$ surplus

373 had also a statistically significant positive impact on purchased concentrated fodder while in

374 case of average $\mathrm{P}$ surplus this relationship did not occur. These two sources frequently

375 determine the N surplus size estimated by "At the farm gate" method (Pietrzak, 2009; Kupiec,

376 2011).

377 In addition to purchased fertilizers and concentrated fodder, the factors that had a significant

378 impact on the results of N, P and K balances were sold plant products as well as sold animal

379 products - it was an inverse relationship. In the $\mathrm{N}$ and $\mathrm{P}$ cases, there were also significant

380 positive correlations between surpluses of these nutrients and their outputs in sold animal

381 products. With regard to $\mathrm{K}$ balances, no such relationships were found.

382 The average $\mathrm{N}$ surplus in farms of the Puck Commune was $120.6 \mathrm{~kg} \mathrm{~N} \cdot \mathrm{ha}^{-1} \mathrm{AL}$ while the

383 average $\mathrm{P}$ surplus was at a level of $-5.0 \mathrm{~kg} \mathrm{P} \cdot \mathrm{ha}^{-1} \mathrm{AL}$ (values of these indicators were

384 characterized by a considerable variety among the surveyed farms). According to various

385 authors works (Godinot et al., 2015; Olofsson, 2015), the levels of N and P surplus determined

386 using farm scale nutrient balance are closely related to their business profile - the largest NP

387 surplus are generated on farms focused on animal production.

388 The broad majority of farms in the Puck Commune $(80.6 \%, \mathrm{n}=25)$ was focused on livestock

389 production, in particular, milk and beef $(48 \%, n=12)$, only pork $(24 \%, n=6)$, only beef $(8 \%, n=2)$,

390 beef and pork production $(24 \%, n=6)$ and horse breeding $(4 \%, n=1)$.Comparing study farms

391 average $\mathrm{N}$ surplus, it can be concluded that its value was smaller in relation to a similar category

392 of French farms (Table 7), while compared to Swedish farms, it was at comparable level (Table

393 8).Comparable in level to farms in Sweden was also an average P surplus calculated for all

394 surveyed farms in the Puck Commune. In view of the fact that in Sweden huge attention to

395 reducing the losses of nutrients from agriculture is paid, especially due to need of counteracting

396 Baltic Sea eutrophication, it seems that N and P surplus generated by farms of the Puck

397 Commune can be considered acceptable in the context of their impact on the environment. 
398 The average surplus of $\mathrm{K}$ - a component regarded as neutral for the environment - in study farms 399 was $10.8 \mathrm{~kg} \mathrm{~K} \cdot \mathrm{ha}^{-1} \mathrm{AL}$. The level of this surplus was $28 \%$ lower than in $\mathrm{K}$ balance found in other

400

401

402

403

404

405

406

407

408

409

410

411

412

413

414

415

416

417

418

419

420

421

422

423

424

425

426

427

researches undertaken in Poland on a comparable group of farms (in terms of number of farms and their specialization of production), but located in a region with more intensive agriculture (Kupiec, 2015).

With regard to the presented results of nitrogen, phosphorus and potassium balance, it should be noted that they might be affected by some uncertainty associated to method of obtaining results for their preparation, based on interviews with farmers. Therefore, it is right to postulate that keeping records on agro-technical practices or nutrient booking containing necessary information for balance sheets preparation should be implemented (in particular records on purchased fertilizers and concentrated fodder as well as sold agricultural products) (Kupiec, Zbierska, 2008).Apart from purely cognitive values of nutrient balance results, they have an educational significance in shaping farmers' awareness. This meaning is widely articulated in many sources and can be expressed in the form of the following opinions and statements:

- The "At the farm gate" nutrient balance method is a basic and simple way to increase knowledge and farmers' awareness about nitrogen, phosphorus and potassium flow - to and from a farm, - creating a starting point for discussion on how to use these components efficiently on farm scale and on impact of NPK and their incomplete use on farm economics as well as the environment (Nilsson, 2013);

- Nutrient balance enables farmers to easily review NPK flow at farm gate level by calculating the amount of nutrient imported and exported to the farm. Thanks to that, a well-prepared nutrient balance can help the farmer to evaluate and improve their nutrient management which can contribute to lower operating costs of the farm by showing the actual amount of nutrients needed for production (Nutrient balance; Farmgate Nutrient Balance Help file PLANET);

- Farm gate nutrient balances are a useful tool to compare farms and farm systems as well as to identify high-risk areas where a lot of nutrients is gathered and hotspots for nutrient emissions (Ramnerö, 2015);

By calculating the nutrient balances at farm gate level, based on the principles of farmers' voluntary participation and through their dialogue with the advisory institutions, an agreement 
428 may be achieved - in order to reduce NPK surpluses and to increase farm profit (Olofsson,

429 2014).

430 In the light of the above, preparation of tool called Integrated agriculture calculator -

431 CalcGosPuck within the WaterPUCK project is well grounded and fully justified. Its

432 dissemination may contribute to broadening farmers' knowledge on correct nutrient management

433 and fertilizer on farm scale and thus reduce environmental pressure exerted by agricultural

434 activities.

435

436 Conclusion

437 The environmental impact of study agricultural holdings in the Puck Commune (which can be 438 taken as representatives of the entire collectivity in this commune) was mainly related to the 439 amount of mineral nitrogen and phosphorus fertilizers consumption in these farms as well as 440 practices and conditions of their use. The mean $\mathrm{N}$ fertilizers consumption per 1 ha of agriculture 441 land in the study area was significantly higher in comparison to their average unit usage in

442 Poland, while the mean consumption of $\mathrm{P}$ fertilizers was slightly lower than the national average.

443 At the time of application these fertilizers, the recommendations for reducing their

444 environmental impact were considered. The amount of purchased $\mathrm{N}, \mathrm{P}$ and $\mathrm{K}$ fertilizers had a

445 significant impact on the results of nutrient balances estimated by the "At the farm gate" method.

446 The results of nutrient balances showed, in particular, that average N, P and K surplus generated

447 by the analyzed farms ranged within the respective levels of $120.6 \mathrm{~kg} \mathrm{~N}, 5.0 \mathrm{~kg} \mathrm{P}$ and $10.8 \mathrm{~kg}$

$448 \mathrm{~K} \cdot \mathrm{ha}^{-1} \mathrm{AL}$. Comparing nutrient surplus amount in agricultural holdings of the Puck Commune to

449 similar farms and farm systems, e.g. in countries with well-developed agriculture, such as France 450 and Sweden, average $\mathrm{N}$ and $\mathrm{P}$ surplus in study area can be assessed as moderate while average $\mathrm{K}$ 451 surplus as being in the range of its average values typical for farms in Poland.

452 Notwithstanding the above, the results of estimated NPK balance well showed their practical

453 dimension. In this regard, it should be indicated that estimating N, P and $\mathrm{K}$ values in a nutrient

454 balance can lead to many practical conclusions helping to reduce the impact of agricultural

455 production on the environment and to improve the farming economy. An example of the latter

456 would be the results of more effective use of nutrients on a farm and lower expenditures on

457 fertilizers and feeds. Therefore, knowledge on how to estimate nutrient balances should be more

458 widely disseminated, especially among farmers and agricultural advisors. Helpful role in this 
459 area can play program developed within the WaterPUCK project called "Integrated agriculture 460 calculator - CalcGosPuck". CalcGosPuck works as an independent application to calculate the 461 pollution emission from agricultural holdings to the environment, including surface and

462 groundwater, but it also can serve to calculate the nutrients' distribution over agricultural areas.

463

464 Acknowledgements

465 We express our gratefulness to the anonymous reviewers for their valuable comments on the

466 earlier versions of the manuscript.

467

468

469

\section{References}

Andraski T.W., Bundy L.G. 2003. Relationships between phosphorus levels in soil and in runoff

470 from corn production systems. J Environ Qual. 32(1): 310-316;

471

Annex of Regulation of the Council of Ministers Decree of June 5, 2018 for adoption of "Action

472

program aimed at reducing the outflow of nitrates from agricultural sources" (J. of Laws, 2018

473 item 1339);

474 Council Directive 91/676/EEC of 12 December 1991 concerning the protection of waters against

475 pollution caused by nitrates from agricultural sources;

476 CSO 2018. Means of production in agriculture in the 2016/2017 farming year - updated tables.

477

Warsaw: Central Statistical Office. Available at: https://stat.gov.pl/obszary-

478 tematyczne/rolnictwo-lesnictwo/rolnictwo/srodki-produkcji-w-rolnictwie-w-roku-gospodarcz

479 ym-20162017,6,14.html (in Polish);

480

Dzierzbicka-Głowacka L., Janecki M., Dybowski D., Szymczycha B., Obarska-Pempkowiak H.,

Wojciechowska E., Zima P., Pietrzak S., Pazikowska-Sapota G., Jaworska-Szulc B., Nowicki A.,

482 Kłostowska Ż., Szymkiewicz A., Galer-Tatarowicz K., Wichorowski M., Białoskórski M.,

483 Puszkarczuk T. 2019. A new approach for investigating the impact of pesticides and nutrient flux

484 from agricultural holdings and land-use structures on the coastal waters of the Baltic Sea. Polish

485 Journal of Environmental Studies 29(5) DOI: 10.15244/pjoes/92524 (in press);

486 Fagerberg B., Salomon E., Steineck S. 1993. The computer program NPK-FLO. Internal

487 Publications - Swedish University of Agricultural Sciences. Department of Crop Production

488 Science 9; 
489 Farmgate Nutrient Balance Help file PLANET, version 3.0. Available at:

$490 \mathrm{http} / /$ www.planet4farmers.co.uk/PlanetWebsiteTutorialsFiles\%5CHelpEngland\%5CPLANET\%

491 20v3\%20Farmgate\%20Nutrient\%20Balance\%20Help.pdf;

492 Godinot O., Leterme P., Vertès F., Faverdin P. Carof M. 2015. Relative nitrogen efficiency, a

493 new indicator to assess crop livestock farming systems. Agronomy for Sustainable Development.

494 35(2): 857-868;

495 Grabowski J. 2009. Chemical composition of mineral fertilizers. Available at:

496 http://www.oschrbialystok.internetdsl.pl/pdf/nawozy_naturalne.pdf (in Polish);

497 Grześkowiak A. 2016. Fertilization of vegetables in the field cultivation. Available at:

498 http://www.polifoska.pl/module-Publikacje-action-Nawozenie-file-content_83.html.html (in

499 Polish);

500 Høgh-Jensen H., Loges R., Jørgensen F.V., Jensen E.S., Vinther F.P. 2004. An empirical model

501 for quantification of symbiotic nitrogen fixation in grass--clover mixtures. Agricultural Systems

502 82: 181-194;

503 Jadczyszyn J., Niedźwiecki J., Debaene G. 2016. Analysis of agronomic categories in different

504 soil texture classification system. Polish Journal of Soil Science XLIX(1): 61-72,

505 DOI:10.17951/pjss.2016.49.1.61;

506 Jakobsson C. 2012. 61 Focus on Nutrients: Advisory Service, Training and Information. In:

507 Jakobsson C., ed. Sustainable Agriculture. Uppsala: Baltic University Press, 461-466;

508 Koelsch R. Lesson 2: Whole Farm Nutrient Planning. Available at: https://articles.

509 extension.org/pages/14850/lesson-2-whole-farm-nutrient-planning;

510 Koelsch R., Franzen A. 2002. Estimating A Whole Farm Nutrient Balance. Available at:

511 https://water.unl.edu/article/animal-manure-management/software\#wfnb;

512 Kucharska D., Staśkiewicz B., Wronka T. 1996. Guide for fertilizing and protecting plants 1997-

513 1998. Warsaw: AGROCHEM- SITR (in Polish);

514 Kupiec J., Zbierska J. 2008. Possibilities of using the balance at the farm gate to assess the

515 potential threat to water quality on the example of farms located in areas covered by the nitrates

516 directive. Melioration and Meadow News 4(419): 189-192 (in Polish);

517 Kupiec J. 2011. Trend of balance and nitrogen balance structure in small-area farms. Science

518 Nature Technologies 5(2) (in Polish); 
519 Kupiec J. 2015. Potassium balance in various specialized small-area farms. Fragm. Agron. 32(2),

520 51-62 (in Polish);

521 Maćkowiak C. 1997. Organic fertilizers in farms and their influence on the environment.

522 Przysiek. ODR (in Polish);

523 Mazur T. 1991. Nitrogen in arable soils. Warsaw: Polish Scientific Publishers (in Polish);

524 Mercik S. 2002. Agricultural chemistry. Theoretical and practical basics. Collective work.

525 Warsaw: SGGW Publisher (in Polish);

526 Miller J.J., Chanasyk D.S., Curtis T.W., Olson B.M. 2011. Phosphorus and nitrogen in runoff

527 after phosphorus- or nitrogen-based manure applications. J Environ Qual. 40(3): 949-958;

528 Nilsson C. 2013. Farm gate nutrient balance. The report prepared within the Baltic Deal project;

529 Nilsson C. 2016. Focus on nutrients. Baltic Deal. Personal communication;

530 Nutrient balance. Available at: http://www.balticdeal.eu/measure/nutrient-balance/;

531 Olofsson S. 2014. The setup for the voluntary nutrient balances in Sweden. Tema: Miljø 84

532 Obligatory or voluntary nutrient balances? Plantekongres - produktion, plan og miljø 350-351;

533 Olofsson S. 2015. Focus on Nutrients, a voluntary on-farm initiative for environment and

534 economy. Available at: https://www.teagasc.ie/media/website/publications/2015/Olofsson_S.pdf;

535 Pietrzak S. 2009. Nitrogen cycling in agricultural macro- and microsystems. Water-

536 Environment-Rural Areas 9(3): 143-158 (in Polish);

537 Pietrzak S. 2013. Preparation of nutrients balance with the method "at the gate of the farm, In:

538 Ulén B., Pietrzak S., Tonderski K. (eds), Farms' self- evaluation in the fields of: nutrients'

539 management and the environmental conditions' analysis. Institute of Technology and Life

540 Sciences in Falenty, Poland, 1-99 (in Polish);

541 Ramnerö B. 2015. Self-evaluation of the Risk of Enhanced Nutrient Leaching by Polish Farmers

542 - Nutrient balances, Soil maps, Farm walks and other tools. Master's Thesis. Swedish University

543 of Agricultural Sciences;

544 Rutkowska A. 2010. Determination of the- AlgaPlant and AlgaminoPlant - growth promoters'

545 impact on the yield green maze mass on green fodder. Research report. Puławy.

546 IUNG-PIB (in Polish);

547 Salomon E., Sundberg M. 2012. Implementation and status of priority measures to reduce N and

548 P leakage. Summary of country reports. Available at: www.balticcompass.org; 
549 Simon J. C., Le Corre L. 1992. The apparent balance of nitrogen at the farm level: methodology,

550 examples of results. Fourrages 129: $79-94$ (in French);

551 Schmidtke K. 2008. How to optimise symbiotic nitrogen fixation in organic crop rotations, In:

552 Organic agriculture in Asia. ISOFAR Conference. 13-14 March 2008. Dankook University,

553 Republic of Korea. Available at: http://orgprints.org/13272/01/13272.doc;

554 Schweder P., Kape E.-H., Brick M. 1998. Informationon fertilization and indicative values for an

555 agricultural practice - Guidelines for the implementation of the fertilizer regulation.

556 Mecklenburg-Vorpommern. Ministry of Agriculture and Nature Conservation (in German);

557 Smith K.A., Jackson D.R., Pepper T.J., 2001. Nutrient losses by surface run-off following the

558 application of organic manures to arable land. 1. Nitrogen. Environ Pollut. 112(1): 41-51.

559 Available at : http://www.ncbi.nlm.nih.gov/pubmed/11202653;

560 Spearman C. 1904. The Proof and Measurement of Association between Two Things. The

561 American Journal of Psychology, 15(1): 72-101. DOI:10.2307/1412159

562 Szewczuk Cz. 2010. Before you sell the straw - the balance of nutrients. Agricultural News

563 Poland. Available at: http://www.wrp.pl/zanim-sprzeda\%C5\%BC-s\%C5\%82om\%C4\%99-

$564 \%$ E2\%80\%93-bilans-substancji-od\%C5\%BCywczych (in Polish);

565 Thayer Ch. 2011. Nutrient Runoff Following Manure Application. Biological Systems

566 Engineering. Dissertations, Theses, and Student Research 17. Available at:

567 http://digitalcommons.unl.edu/biosysengdiss/17

568 The Act of July 10, 2007 on fertilizers and fertilizing (J. of Laws, 2007 No. 147, item 1033);

569 Ulén B., Pietrzak S., Tonderski K., 2013. Farms’ self- evaluation in the fields of: nutrients'

570 management and the environmental conditions' analysis. Institute of Technology and Life

571 Sciences in Falenty, Poland. 1-99 (in Polish);

572 Wrzaszcz W. 2009. Nutrients Balance and the balance sheet of organic matter in individual

573 farms. The research on the socially sustainable agriculture. T7. multi-annual program 2005-2009.

574 The economic and social conditions for the development of Polish food economy after Polish

575 accession to the European Union. Warsaw, Poland, IERiGŻ-PIB. 1-98 (in Polish). 
Figure 1

Map of the study area: Puck District and Bay of Puck.

The Bay of Puck, southern Baltic Sea is an example of a region that is highly vulnerable to anthropogenic impact. Therefore, it has been included into Natura 2000.

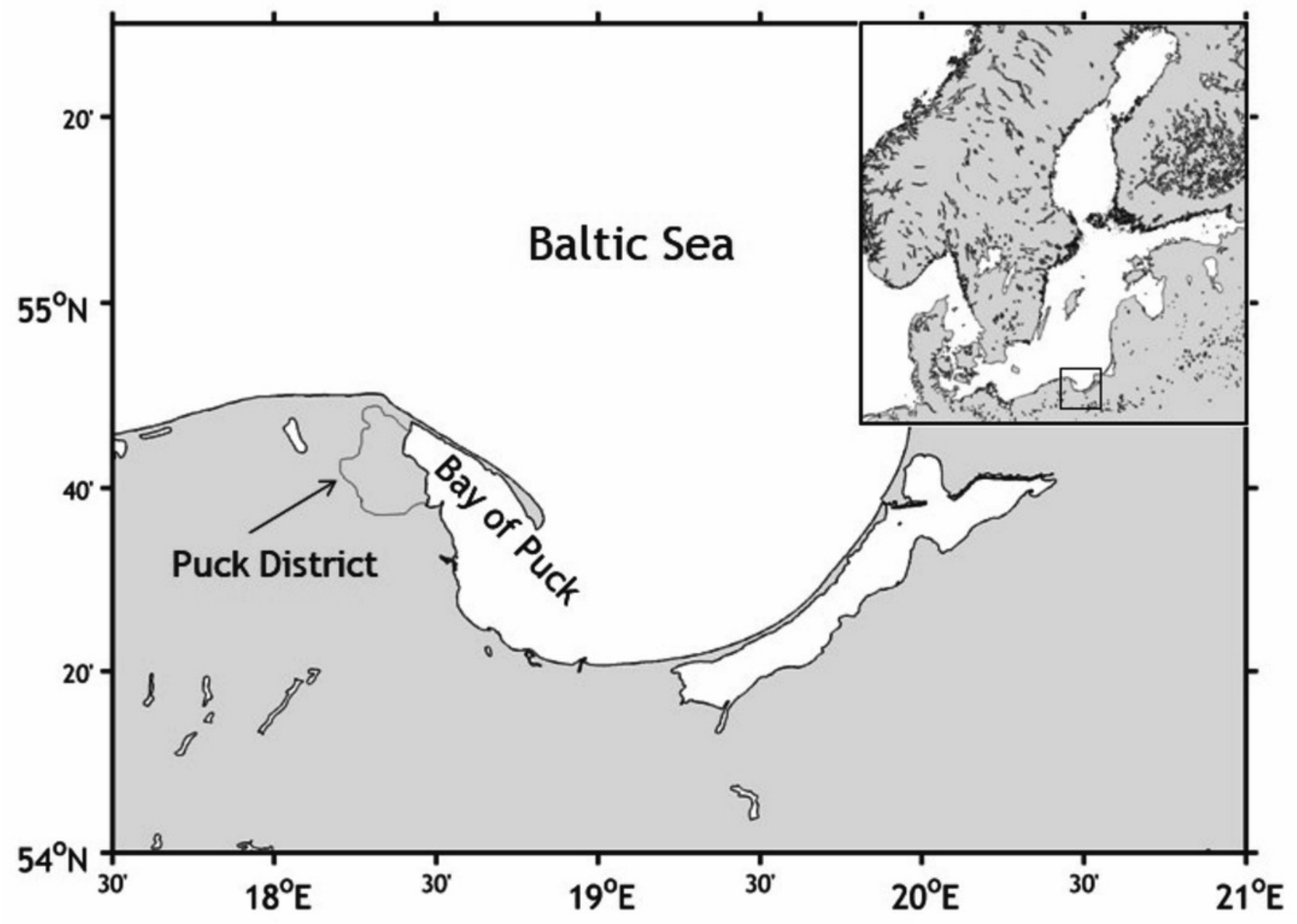




\section{Figure 2}

The shame of the WaterPUCK service.

Integrated information and prediction Service WaterPUCK includes surface water model (based on SWAT Soil and Water Assessment Tool), groundwater flow model (based on Modflow code), 3D environmental model of the Bay of Puck EcoPuckBay (based on the POP code and 3D CEMBS model of the Battic Sea) and integrated agriculture calculator called "CalcGosPuck" plus large Database WaterPUCK.

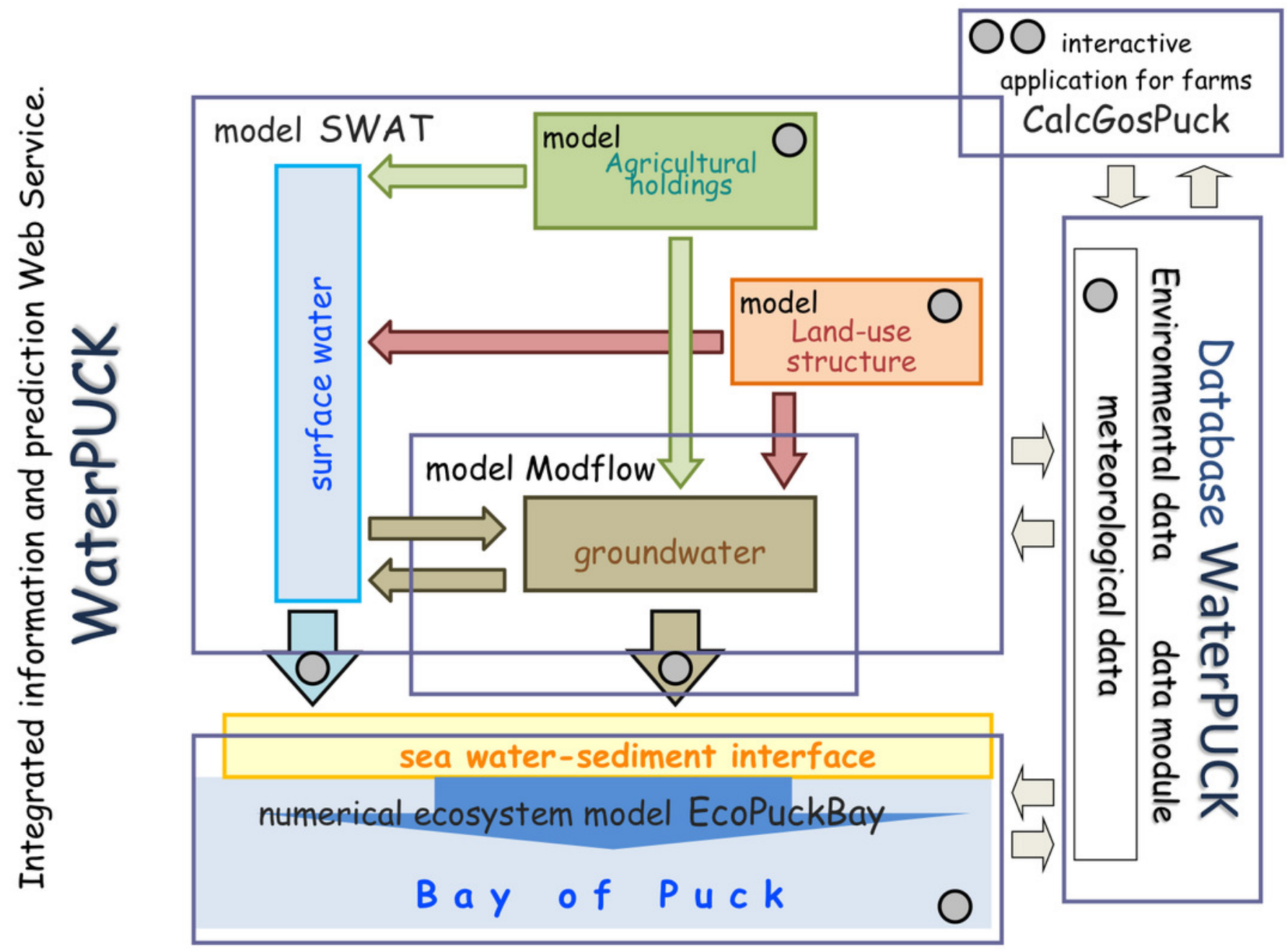


Figure 3

Schema of the nutrient balance method "At the farm gate"; own elaboration (Pietrzak 2013).

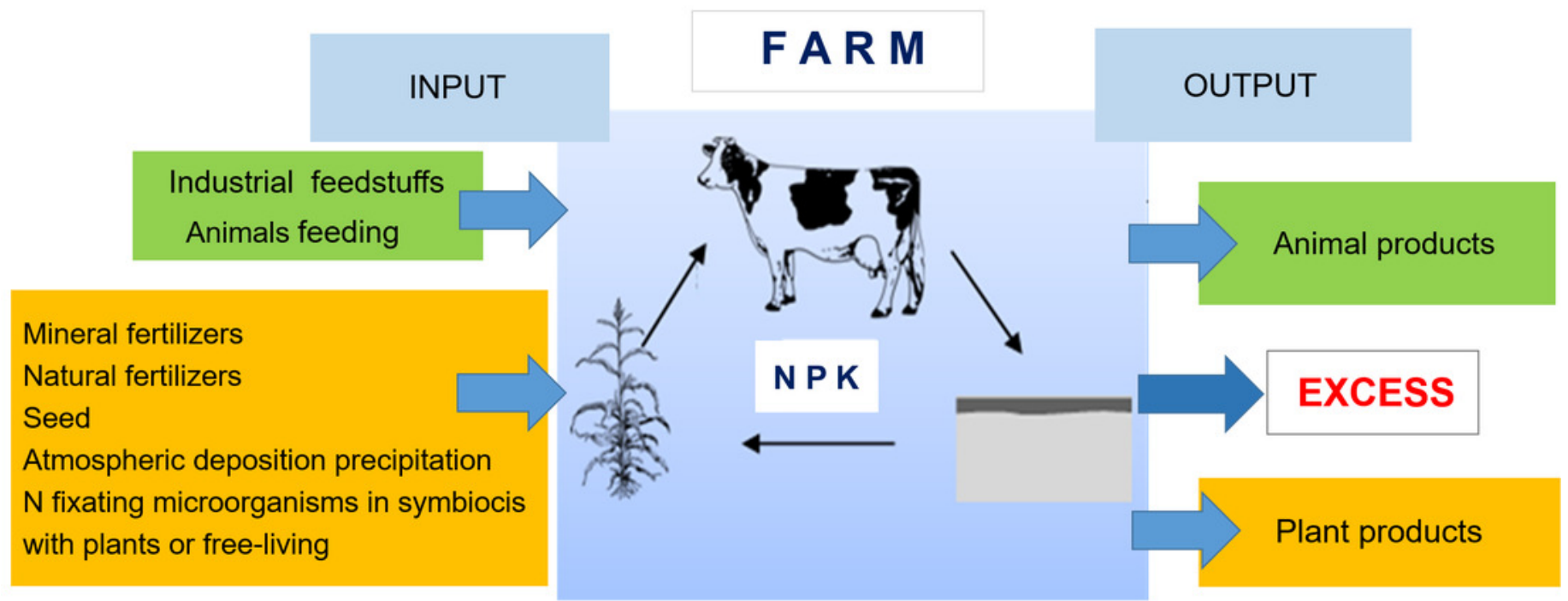




\section{Figure 4}

Type and area of arable land or grassland in farms participating in the WaterPUCK project.

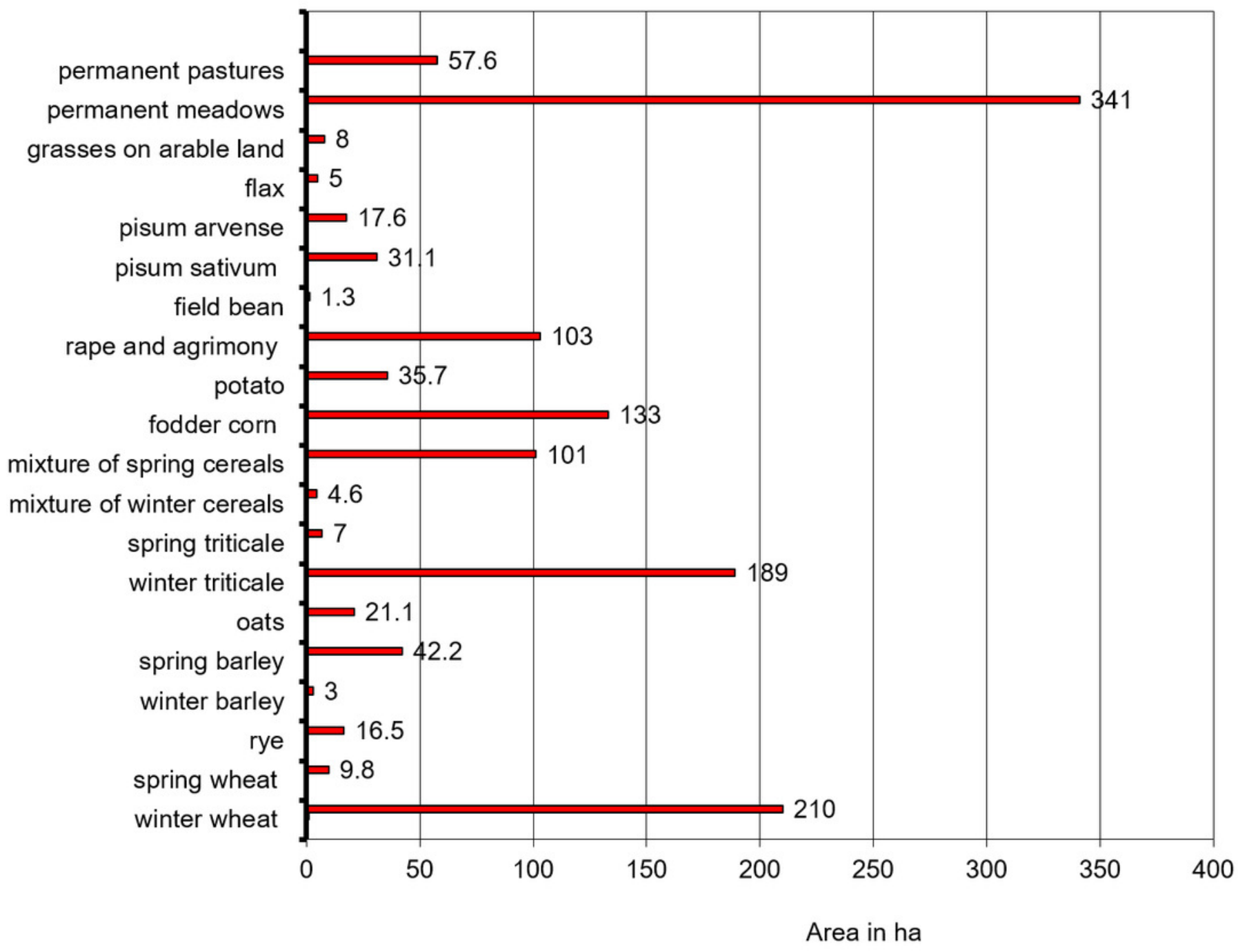




\section{Figure 5}

The selection page of the CalcGosPuck agricultural's calculator
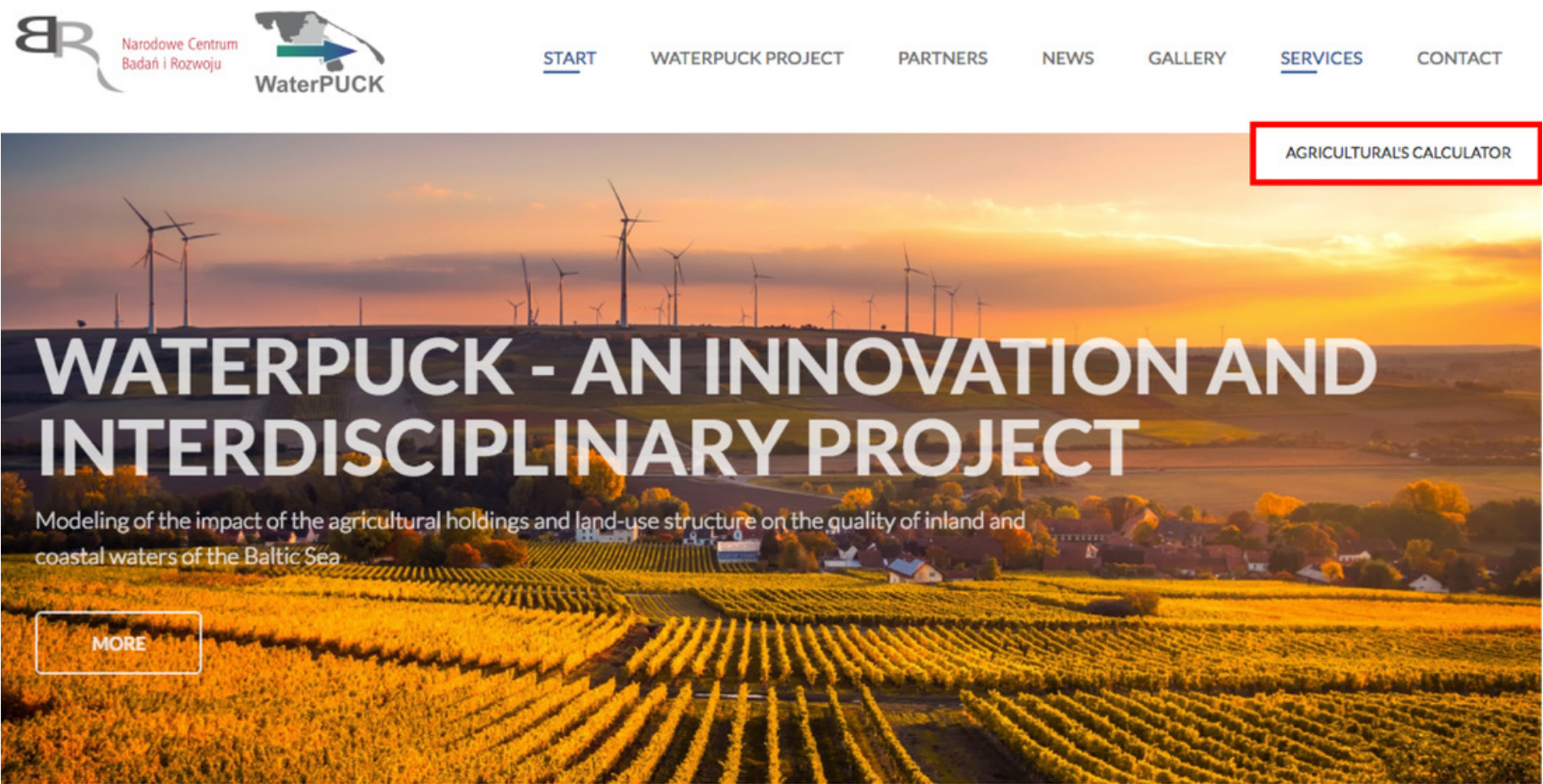
Figure 6

Calculating nutrients balance in farm. Choose parameters for farm. 


\begin{tabular}{|l|lcrr|}
\hline & Agricultural holding's balance & & \\
\hline & & N & P & K \\
\hline Inputs [kg]: & 10996.00 & 609.00 & 645.95 \\
\hline Outputs [kg]: & 1977.50 & 375.90 & 530.95 \\
\hline Surplus [kg]: & 9018.50 & 233.10 & 115.00 \\
\hline Efficiency [\%]: & 17.98 & 61.72 & 82.20 \\
\hline
\end{tabular}

a

\begin{tabular}{l}
$\begin{array}{l}\text { Area of agricultural } \\
\text { land [ha] }\end{array}$ \\
\hline
\end{tabular}

b Voivodeship Pomeranian $\quad \rightarrow$

C

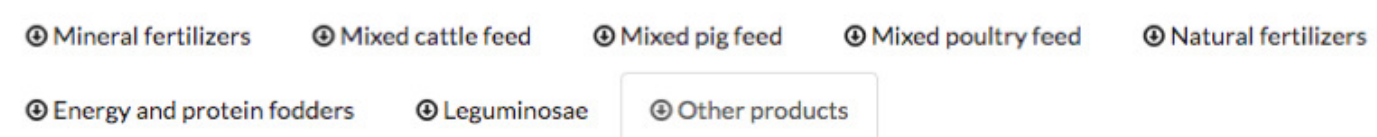

E Animal products

\begin{tabular}{|c|c|}
\hline name & lount [dt] \\
\hline Dairy cattle $(550 \mathrm{~kg})$ & 35 \\
\hline Milk & 3500 \\
\hline
\end{tabular}

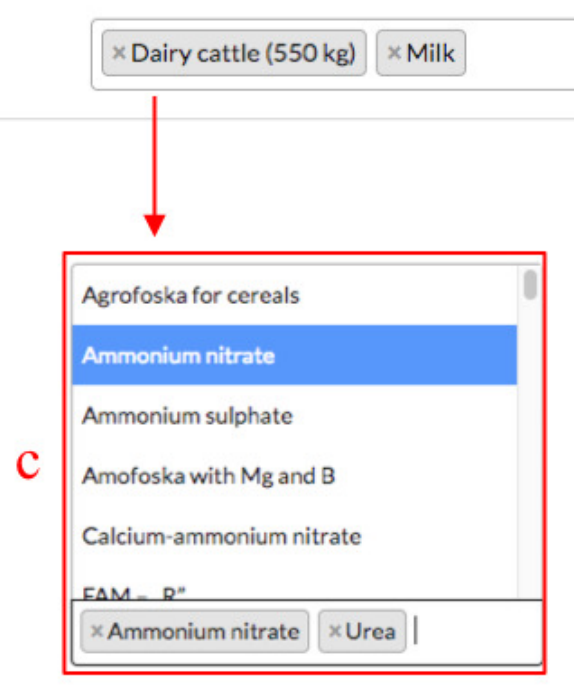

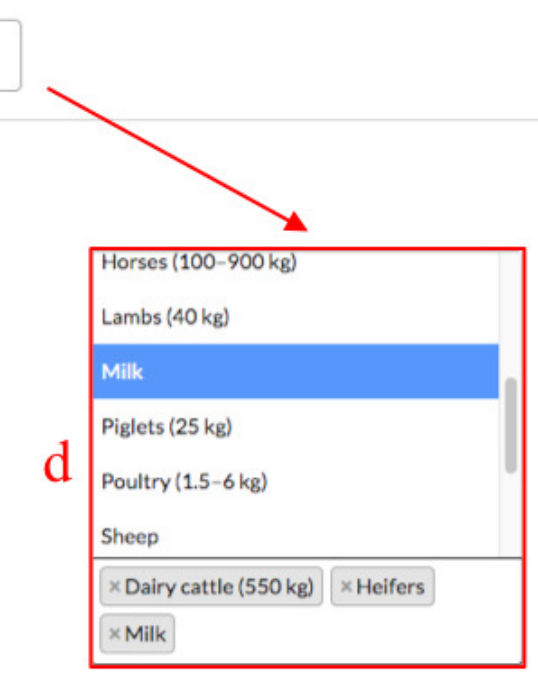

Lower Silesian

Kuyavian-Pomeranian

Lublin

Lubusz

Łódź

Lesser Poland

Masovian

Opole

Subcarpathian

Podlaskie

$\checkmark$ Pomeranian

Silesian

Holy Cross

Warmian-Masurian

Greater Poland

West Pomeranian 
Figure 7

The consumption of nitrogen fertilizers in individual farms in farms participating in the WaterPUCK project.

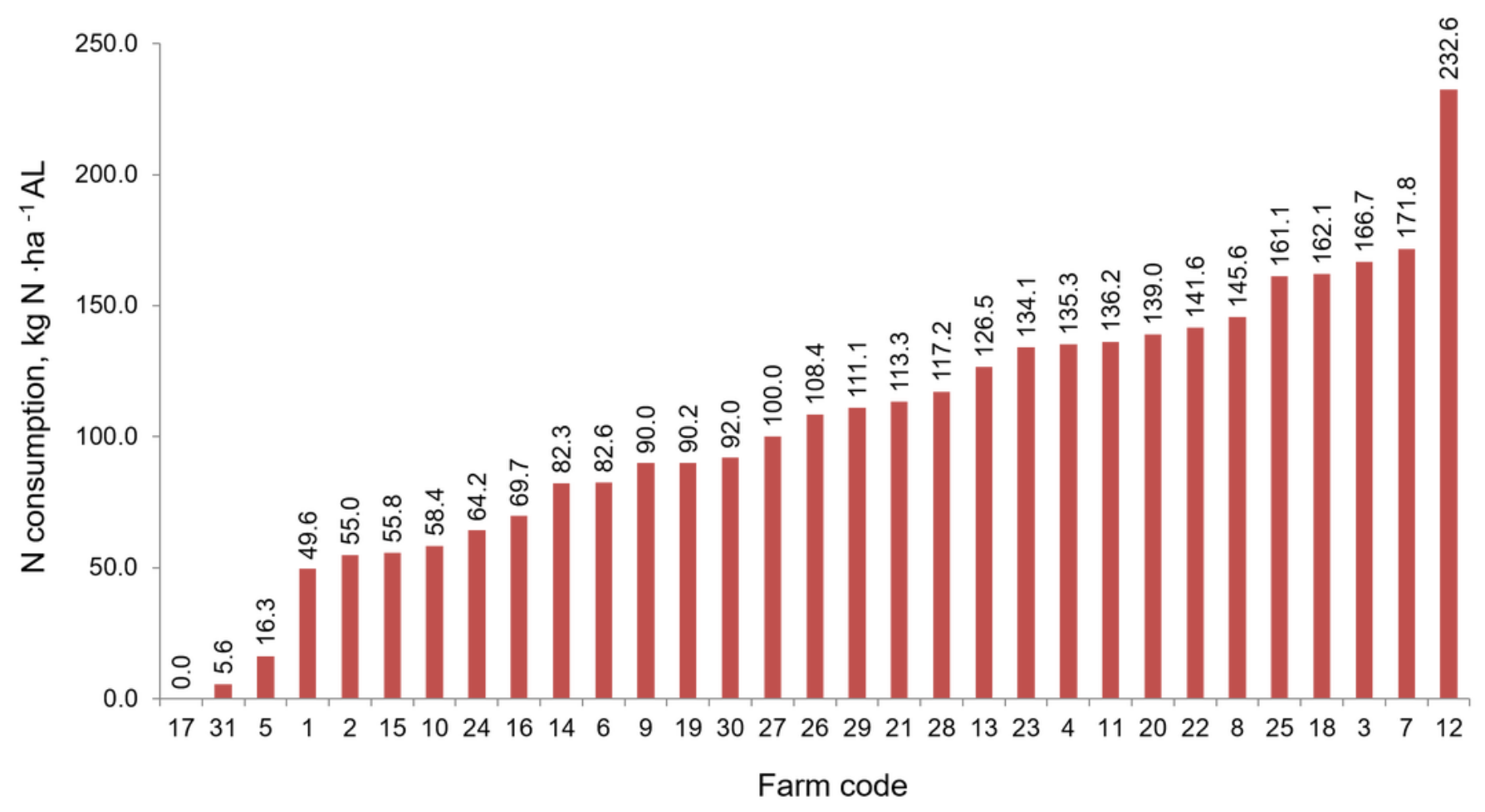


Figure 8

The consumption of phosphorus fertilizers in the individual farms in farms participating in the WaterPUCK project.

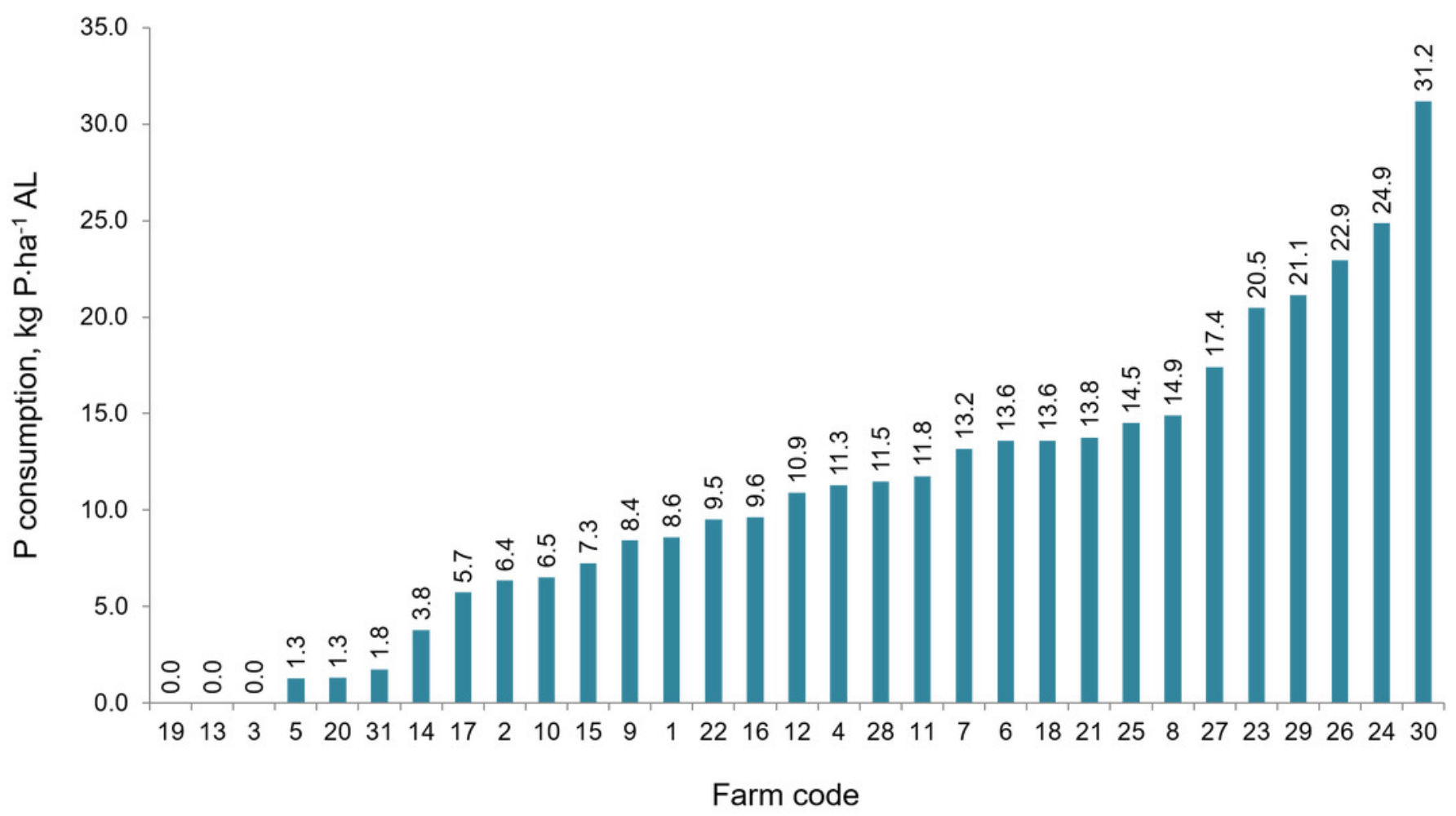


Figure 9

The consumption of potassium fertilizers in the individual farms in farms participating in the WaterPUCK project.

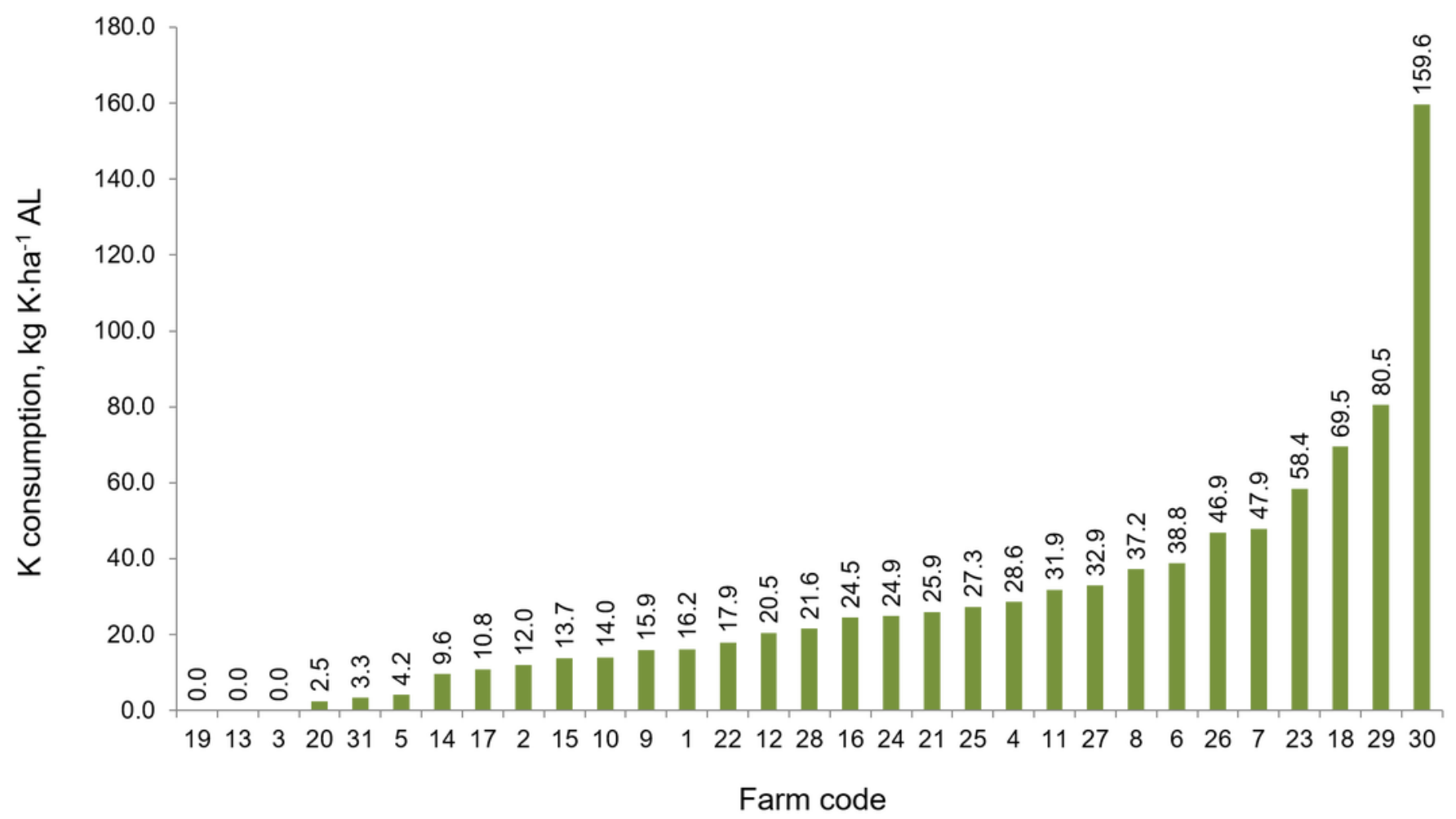


Figure 10

Surplus and efficiency of nitrogen $(\mathrm{N})$ use in farms participating in the WaterPUCK project.

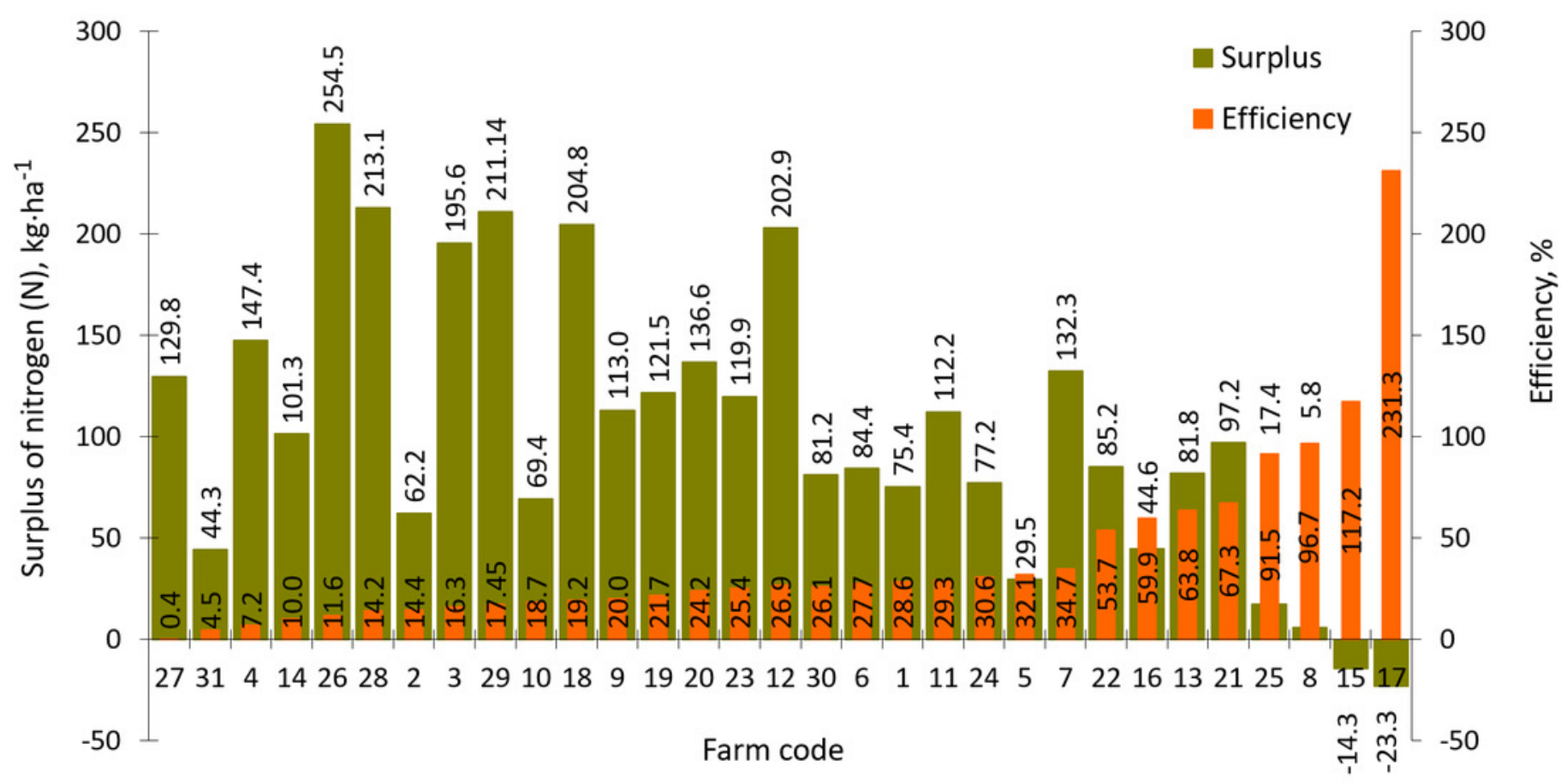


Figure 11

Surplus and efficiency of phosphorus (P) use in farms participating in the WaterPUCK project.

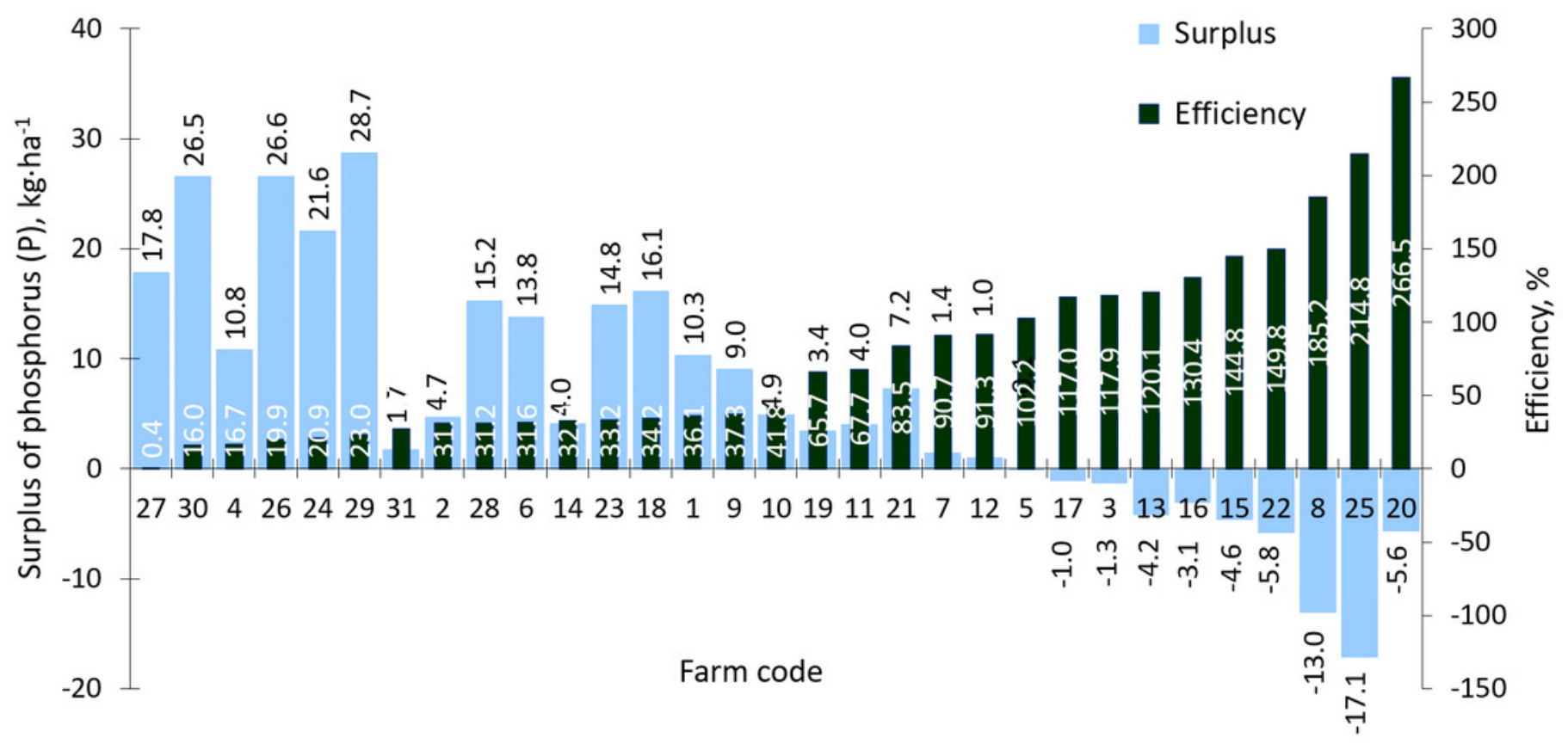




\section{Figure 12}

Surplus and efficiency of phosphorus (K) use in farms participating in the WaterPUCK project.

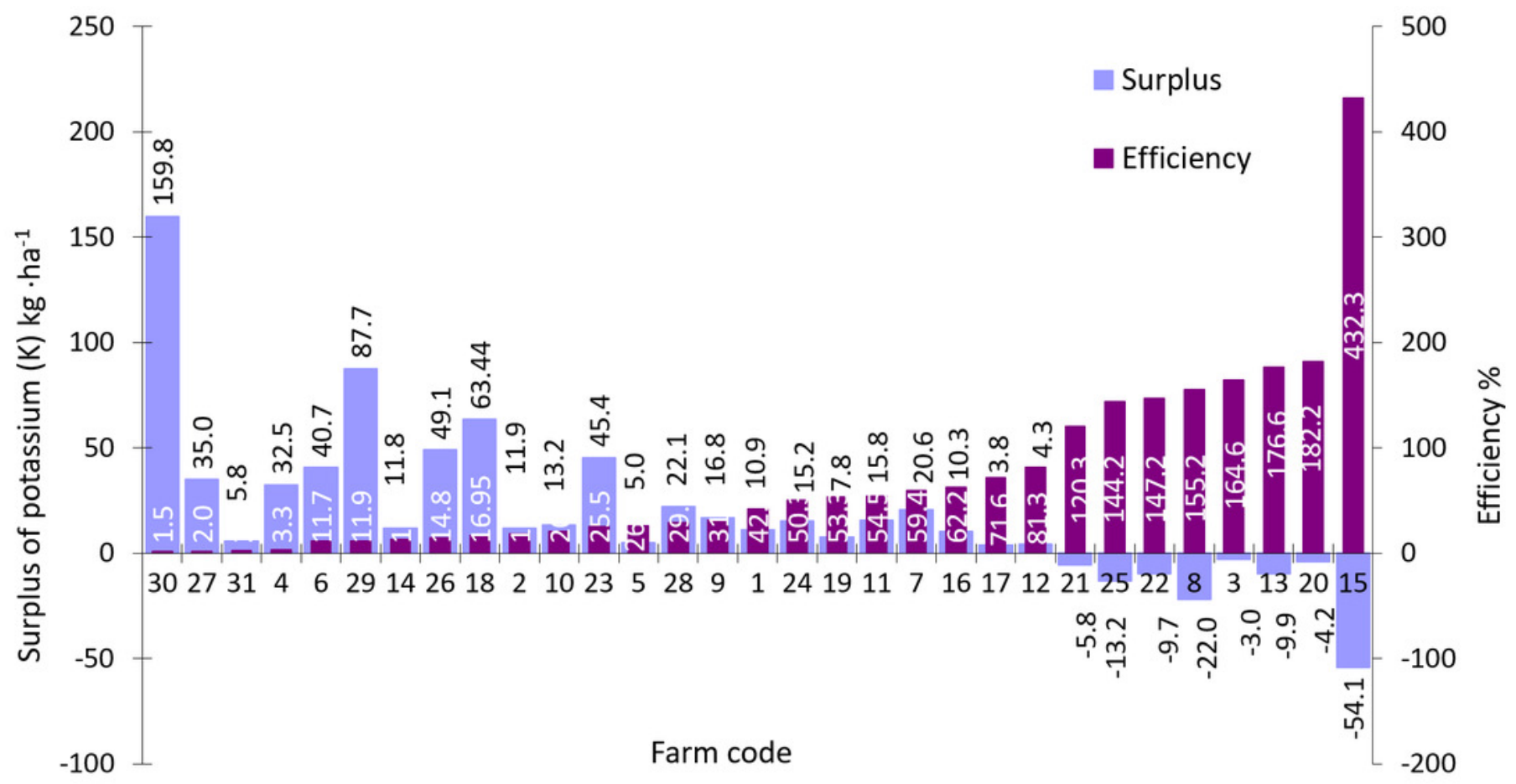




\section{Table $\mathbf{1}$ (on next page)}

Animal population, type and the maintenance system in study farms of Puck Commune. 


\begin{tabular}{|c|c|c|c|c|c|c|c|}
\hline \multirow{2}{*}{$\begin{array}{l}\text { Farm } \\
\text { Code }\end{array}$} & \multirow{2}{*}{$\begin{array}{l}\text { Farm } \\
\text { area } \\
\text { (in ha) }\end{array}$} & \multirow{2}{*}{$\begin{array}{l}\text { Profile of the animal } \\
\text { production }\end{array}$} & \multicolumn{2}{|c|}{$\begin{array}{l}\text { Stocking } \\
\text { density }\end{array}$} & \multicolumn{3}{|c|}{$\begin{array}{l}\text { Production of nitrogen in natural } \\
\text { fertilizers }\end{array}$} \\
\hline & & & LU & $\mathrm{LU} \mathrm{ha}^{-1}$ & $\begin{array}{l}\text { Animals } \\
\text { maintanance } \\
\text { system }\end{array}$ & $\mathrm{kg} \mathrm{N}$ & $\mathrm{kg} \mathrm{N} \mathrm{ha}^{-1}$ \\
\hline 1 & 48 & milk and beef livestock & 51.3 & 1.1 & shallow litter & 2308 & 48 \\
\hline 3 & 81 & milk and beef livestock & 85.6 & 1.1 & shallow litter & 3843 & 48 \\
\hline 4 & 17.3 & beef and pork livestock & 18.4 & 1.1 & shallow litter & 495 & 27 \\
\hline 5 & 51.5 & beef and pork livestock & 15.4 & 0.3 & shallow litter & 917 & 18 \\
\hline 6 & 16 & $\begin{array}{l}\text { milk and beef } \\
\text { livestock. }\end{array}$ & 14.3 & 0.9 & shallow litter & 772 & 48 \\
\hline 7 & 38.2 & beef livestock & 21.2 & 0.6 & shallow litter & 723 & 19 \\
\hline 9 & 70 & milk and beef livestock & 70.3 & 1.0 & shallow litter & 3192 & 46 \\
\hline 10 & 29.5 & milk and beef livestock & 47.3 & 1.6 & shallow litter & 1899 & 64 \\
\hline 11 & 18 & beef and pork livestock. & 8.3 & 0.5 & shallow litter & 422 & 24 \\
\hline 13 & 43 & pork livestock & 52.4 & 1.2 & shallow litter & 3402 & 79 \\
\hline 14 & 10.5 & pork livestock & 2.9 & 0.3 & shallow litter & 214 & 28 \\
\hline 15 & 100 & milk and beef livestock & 61.6 & 0.7 & shallow litter & 2662 & 30 \\
\hline 18 & 77.5 & pork livestock. & 67.6 & 0.8 & litter free & 4449 & 56 \\
\hline 19 & 120 & milk and beef livestock & 148.6 & 1.2 & shallow litter & 6527 & 54 \\
\hline 20 & 45 & beef livestock. & 34.4 & 0.8 & shallow litter & 1171 & 26 \\
\hline 21 & 15 & pork livestock. & 45.0 & 3.0 & shallow litter & 2073 & 138 \\
\hline 22 & 62 & milk and beef livestock & 36.6 & 0.6 & shallow litter & 1603 & 26 \\
\hline 23 & 36 & milk and beef livestock & 24.0 & 0.7 & shallow litter & 1095 & 30 \\
\hline 24 & 7.24 & pork livestock & 5.42 & 0.8 & shallow litter & 349 & 48 \\
\hline 26 & 118 & $\begin{array}{l}\text { milk and beef } \\
\text { livestock. }\end{array}$ & 45.5 & 0.4 & shallow litter & 4716 & 40 \\
\hline 27 & 19 & $\begin{array}{l}\text { farming and horse } \\
\text { breeding }\end{array}$ & 24.7 & 1.3 & shallow litter & 836 & 40 \\
\hline 28 & 38 & milk and beef livestock & 41.9 & 1.1 & shallow litter & 1828 & 48 \\
\hline 29 & 16.5 & milk and beef livestock & 34.9 & 2.1 & $\begin{array}{l}\text { deep/ shallow } \\
\text { litter }\end{array}$ & 2385 & 145 \\
\hline 30 & 5.0 & pork livestock & 6.4 & 1.3 & shallow litter & 398 & 80 \\
\hline 31 & 13 & beef and pork livestock. & 1.3 & 0.01 & deep litter & 70 & 5 \\
\hline
\end{tabular}




\section{Table 2 (on next page)}

The profile of production systems in the study farms in the Puck Commune.

${ }^{1}$ no livestock production (plant production only) 
2

\begin{tabular}{c|c|c}
\hline Production System & No. of Farms & Proportion of Total (\%) \\
\hline Milk and Beef & 12 & 38.7 \\
\hline Pork only & 6 & 19.4 \\
\hline Pork and Beef & 4 & 12.9 \\
\hline Beef only & 2 & 6.5 \\
\hline Horse Breeding $^{\text {None }}$ & 1 & 3.2 \\
\hline
\end{tabular}

3 


\section{Table 3(on next page)}

Consumption of mineral fertilizers (calculated on the pure ingredient) per 1ha of agricultural land in the marketing year of 2016/2017.

*CSO 2018. Means of production in agriculture in the $2016 / 2017$ farming year - updated tables. Warszawa. Central Statistical Office. Available online:: https://stat.gov.pl/obszarytematyczne/rolnictwo-lesnictwo/rolnictwo/srodki-produkcji-w-rolnictwie-w-rokugospodarczym-20162017,6,14.html (in Polish). 
1

\begin{tabular}{c|c|c|c|c}
\hline \multirow{2}{*}{ Area } & \multicolumn{4}{|c}{ Mineral fertilizers consumption. kg.ha' ${ }^{-1}$ AL } \\
\cline { 2 - 5 } & $\begin{array}{c}\text { Total } \\
\text { (NPK) }\end{array}$ & Nitrogen (N) & Phosphorus (P) & Potassium (K) \\
\hline Poland* & 121.6 & 79.4 & 10.3 & 31.9 \\
\hline $\begin{array}{c}\text { Pomeranian } \\
\text { Voivodship* }\end{array}$ & 121.1 & 82.8 & 8.8 & 29.5 \\
\hline $\begin{array}{c}\text { Farms surveyed } \\
\text { - average }\end{array}$ & $\mathbf{1 4 7 . 1}$ & $\mathbf{1 1 4 . 9}$ & $\mathbf{9 . 3}$ & $\mathbf{2 2 . 9}$ \\
\hline
\end{tabular}

2 


\section{Table 4(on next page)}

The relationship between the surplus of $\mathrm{N}$ and selected factors.

Correlation Spearman ranks order, marked (in red) correlations are significant - with $p<$ 0.05 . 


\begin{tabular}{|c|c|c|c|c|c|c|}
\hline & $\begin{array}{c}\text { Surplus } \\
\mathrm{N} \\
\left(\mathrm{kg} \cdot \mathrm{ha}^{-1}\right)\end{array}$ & $\begin{array}{l}\text { Efficiency } \\
(\%)\end{array}$ & $\begin{array}{l}\text { Nitrogen in } \\
\text { mineral } \\
\text { fertilizers } \\
\left(\mathrm{kg} \cdot \mathrm{ha}^{-1}\right)\end{array}$ & $\begin{array}{l}\text { Nitrogen in } \\
\text { feeds } \\
\left(\mathrm{kg} \cdot \mathrm{ha}^{-1}\right)\end{array}$ & $\begin{array}{l}\mathrm{N} \text { share in the } \\
\text { sold animal } \\
\text { production } \\
(\%)\end{array}$ & $\begin{array}{l}\mathrm{N} \text { share } \\
\text { in the } \\
\text { sold } \\
\text { plant } \\
\text { production } \\
(\%)\end{array}$ \\
\hline Surplus N $\left(\mathrm{kg}^{\prime} \mathrm{ha}^{-1}\right)$ & 1.00 & & & & & \\
\hline Efficiency (\%) & -0.58 & 1.00 & & & & \\
\hline $\begin{array}{l}\text { Nitrogen in mineral } \\
\text { fertilisers }\left(\mathrm{kg} \cdot \mathrm{ha}^{-1}\right)\end{array}$ & 0.57 & 0.04 & 1.00 & & & \\
\hline $\begin{array}{l}\text { Nitrogen in feed } \\
\left(\mathrm{kg} \cdot \mathrm{ha}^{-1}\right)\end{array}$ & 0.48 & -0.18 & 0.03 & 1.00 & & \\
\hline $\begin{array}{l}\mathrm{N} \text { share in the sold } \\
\text { animal production } \\
(\%)\end{array}$ & 0.36 & -0.53 & -0.20 & 0.64 & 1.00 & \\
\hline $\begin{array}{l}\mathrm{N} \text { share in the sold } \\
\text { plant production }(\%)\end{array}$ & -0.36 & 0.53 & 0.20 & -0.64 & -1.00 & 1.00 \\
\hline
\end{tabular}




\section{Table 5(on next page)}

The relationship between the P surplus and selected factors.

Correlation of the Spearman ranks order, marked (in red) correlations are significant - with $p$ $<0.05$. 
1

2

\begin{tabular}{|c|c|c|c|c|c|c|}
\hline & $\begin{array}{l}\text { Surplus P } \\
\left(\mathrm{kg} \cdot \mathrm{ha}^{-1}\right)\end{array}$ & $\begin{array}{c}\text { Efficiency } \\
(\%)\end{array}$ & $\begin{array}{c}\text { Phosphorus } \\
\text { in mineral } \\
\text { fertilizers } \\
\left(\mathrm{kg}^{\circ} \mathrm{ha}^{-1}\right)\end{array}$ & $\begin{array}{l}\text { Phosphorus } \\
\text { in feeds } \\
\left(\mathrm{kg} \cdot \mathrm{ha}^{-1}\right)\end{array}$ & $\begin{array}{l}\text { P share in } \\
\text { the sold } \\
\text { animal } \\
\text { production } \\
(\%)\end{array}$ & $\begin{array}{l}\text { P share in } \\
\text { the sold } \\
\text { plant } \\
\text { production } \\
(\%)\end{array}$ \\
\hline Surplus $\mathrm{P}\left(\mathrm{kg} \cdot \mathrm{ha}^{-1}\right)$ & 1.00 & & & & & \\
\hline Efficiency (\%) & -0.91 & 1.00 & & & & \\
\hline $\begin{array}{l}\text { Phosphorus in } \\
\text { mineral fertilisers } \\
\left(\mathrm{kg} \cdot \mathrm{ha}^{-1}\right)\end{array}$ & 0.57 & -0.43 & 1.00 & & & \\
\hline $\begin{array}{l}\text { Phosphorus in feed } \\
\left(\mathrm{kg} \cdot \mathrm{ha}^{-1}\right)\end{array}$ & 0.33 & -0.10 & -0.04 & 1.00 & & \\
\hline $\begin{array}{l}\text { P share in the sold } \\
\text { animal production } \\
(\%)\end{array}$ & 0.44 & -0.44 & -0.12 & 0.51 & 1.00 & \\
\hline $\begin{array}{l}\text { P share in the sold } \\
\text { plant production } \\
(\%)\end{array}$ & -0.44 & 0.44 & 0.12 & -0.51 & -1.00 & 1.00 \\
\hline
\end{tabular}

3

4

5

6

7

8

9

10 


\section{Table 6(on next page)}

The relationship between the $K$ surplus and selected factors.

Correlation of the Spearman ranks order, marked (in red) correlations are significant - with $p$ $<0.05$. 


\begin{tabular}{l|c|c|c|c|c|c}
\hline & $\begin{array}{c}\text { Surplus K, } \\
\mathrm{kg} \cdot \mathrm{ha}^{-1}\end{array}$ & $\begin{array}{c}\mathrm{K} \text { efficiency, } \\
\%\end{array}$ & $\begin{array}{c}\mathrm{K} \text { in mineral } \\
\text { fertilizers, } \\
\mathrm{kg} \cdot \mathrm{ha}^{-1}\end{array}$ & $\begin{array}{c}\mathrm{K} \text { in feeds, } \\
\mathrm{kg} \cdot \mathrm{ha}^{-1}\end{array}$ & $\begin{array}{c}\mathrm{K} \text { in sold } \\
\text { animal } \\
\text { products, } \\
\mathrm{kg} \cdot \mathrm{ha}^{-1}\end{array}$ & $\begin{array}{c}\mathrm{K} \text { in sold } \\
\text { plant } \\
\text { products, } \\
\mathrm{kg} \cdot \mathrm{ha}^{-1}\end{array}$ \\
\hline Surplus $\mathrm{K}, \mathrm{kg} \cdot \mathrm{ha}^{-1}$ & 1.00 & 1.00 & & & & \\
\hline $\mathrm{K}$ efficiency, \% & -0.81 & -0.41 & 1.00 & & & \\
\hline $\begin{array}{l}\mathrm{K} \text { in mineral } \\
\text { fertilizers, } \mathrm{kg} \cdot \mathrm{ha}^{-1}\end{array}$ & 0.65 & -0.19 & 0.01 & 1.00 & & \\
\hline $\mathrm{K}$ in feed, $\mathrm{kg} \cdot \mathrm{ha}^{-1}$ & 0.36 & -0.06 & 0.02 & 0.52 & 1.00 & \\
\hline $\begin{array}{l}\mathrm{K} \text { in sold animal } \\
\text { products, } \mathrm{kg} \cdot \mathrm{ha}^{-1}\end{array}$ & 0.26 & 0.62 & 0.14 & -0.40 & -0.48 & 1.00 \\
\hline $\begin{array}{l}\mathrm{K} \text { in sold plant } \\
\text { products, } \mathrm{kg} \cdot \mathrm{ha}^{-1}\end{array}$ & -0.52 & & & & & \\
\hline
\end{tabular}




\section{Table 7 (on next page)}

Mean surplus $\mathrm{N}$ and $\mathrm{N}$-efficiency in nine farming system categories in France (based on: Godinot et al., 2015). 
2

\begin{tabular}{|c|c|c|c|c|c|c|c|c|c|}
\hline & \multicolumn{9}{|c|}{ Farming system categories } \\
\hline & 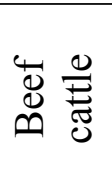 & 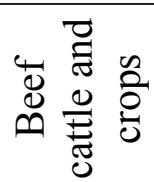 & 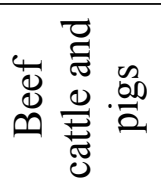 & 官 & 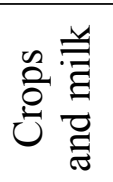 & $\stackrel{y}{z}$ & 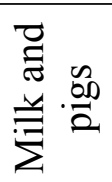 & $\stackrel{\infty}{\infty}$ & $\underset{\Xi}{\stackrel{\Xi}{E}}$ \\
\hline Number of farms & 47 & 35 & 13 & 24 & 53 & 299 & 36 & 30 & 20 \\
\hline $\begin{array}{l}\text { Surplus } N \\
\left(\mathrm{~kg} \mathrm{~N} \cdot \mathrm{ha}^{-1} \mathrm{AL}\right)\end{array}$ & 228 & 128 & 448 & 141 & 124 & 245 & 420 & 852 & 377 \\
\hline N-efficiency (\%) & 11.6 & 30.4 & 17.5 & 41.7 & 27.9 & 16.9 & 21.9 & 23.5 & 26.8 \\
\hline
\end{tabular}

3

4

5 


\section{Table 8 (on next page)}

Farm gate balances of conventional farms in southern Sweden (based on: Olofsson, 2015). 
1

\begin{tabular}{l|c|c|c}
\hline \multirow{2}{*}{} & \multicolumn{3}{|c}{ Type of farms } \\
\cline { 2 - 4 } & Crop & Dairy & Pig \\
\hline Number of farms & 965 & 976 & 204 \\
\hline Surplus N (kg N.ha-1 AL) & 45 & 143 & 104 \\
\hline Surplus P (kg P.ha-1 AL) & -1.4 & 4.7 & 7.6 \\
\hline
\end{tabular}

2

3

4 